\title{
RSCPublishing Journalof
}

\section{Modulating the cytocompatibility of tridimensional carbon nanotube-based scadffolds}

\begin{tabular}{|r|l|}
\hline Journal: & Journal of Materials Chemistry B \\
\hline Manuscript ID: & Draft \\
\hline Article Type: & Paper \\
\hline Date Submitted by the Author: & $\mathrm{n} / \mathrm{a}$ \\
\hline Complete List of Authors: & $\begin{array}{l}\text { Nardecchia, Stefania; Instituto de Ciencia de Materiales de Madrid (ICMM) } \\
\text { Consejo Superior de Investigacines Científicas (CSIC), Biomateriales y } \\
\text { Materiales Bioinspirados } \\
\text { Serrano, Maria; Instituto de Ciencia de Materiales de Madrid (ICMM) } \\
\text { Consejo Superior de Investigacines Científicas (CSIC), Biomateriales y } \\
\text { Materiales Bioinspirados } \\
\text { Gutierrez, Maria; Instituto de Ciencia de Materiales de Madrid (ICMM) } \\
\text { Consejo Superior de Investigacines Científicas (CSIC), Biomateriales y } \\
\text { Materiales Bioinspirados } \\
\text { Ferrer, Maria; Instituto de Ciencia de Materiales de Madrid (ICMM) Consejo } \\
\text { Superior de Investigacines Científicas (CSIC), Biomateriales y Materiales } \\
\text { Bioinspirados } \\
\text { del Monte, Francisco; Instituto de Ciencia de Materiales de Madrid (ICMM) } \\
\text { Consejo Superior de Investigacines Científicas (CSIC), Biomateriales y } \\
\text { Materiales Bioinspirados }\end{array}$ \\
\hline
\end{tabular}




\title{
Modulating the cytocompatibility of tridimensional carbon nanotube- based scadffolds
}

\author{
Stefania Nardecchia, ${ }^{a}$ María Concepción Serrano, ${ }^{*, a}$ María Concepción Gutiérrez, ${ }^{a}$ María Luisa Ferrer, ${ }^{a}$ \\ and Francisco del Monte ${ }^{*, a}$
}

\author{
${ }_{5}$ Received (in $\left.X X X, X X X\right)$ Xth $X X X X X X X X X 20 X X$, Accepted Xth $X X X X X X X X X 20 X X$ \\ DOI: $10.1039 / b 000000 x$
}

\begin{abstract}
Carbon nanotubes (CNTs) have lately attracted significant attention in the field of biomedicine. Although a wide repertoire of CNT-based composites has been explored as substrates for cell growth, the fabrication of 3D scaffolds has been more rarely accomplished. Additionally, concerns referred to CNT 10 biocompatibility make their use in biomaterials still controversial. Herein we explore the interaction of three types of CNT-based 3D scaffolds - prepared with multi-walled CNTs and processed to show different architectural and morphological features at the microscale by using three different polymers (i.e., chitosan, chondroitin sulphate and gelatin) - with three types of mammalian cells displaying different size and adhesion pattern. Cell-material interaction has been assessed by studying cell viability, 15 adhesion, morphology, and apoptosis. By means of time-lapse confocal laser scanning microscopy, we investigate, for the first time in CNT-based scaffolds, cell migration processes in real time. Scaffolds displaying both a pore size in range with that of cells and lower surface roughness reveal the highest viability values. On the contrary, those with a smaller pore size and higher surface roughness account for the lowest cytocompatibility. Results from these studies benefit the fabrication of optimized biomaterials 20 by varying scaffold-dependent parameters in accordance to those of target cells.
\end{abstract}

\section{Introduction}

Carbon nanotubes (CNTs) are defined as hollow cylinders exclusively composed of graphitic carbon sheets generally rolled as either a single-walled structure (SWCNTs) or a multi-walled ${ }_{25}$ structure (MWCNTs). Since their discovery by Iijima and others, ${ }^{1,2}$ an extensive progress has been done in an attempt to use CNTs as brick elements for the development of advanced materials with remarkable electrical, thermal and mechanical properties. In this sense, the fabrication of diverse CNT-based 30 composites has opened their use in a wide repertoire of applications, from flexible electrodes in displays to highperformance composites for aircraft and automotive industries. ${ }^{3,4}$ CNTs have also attracted significant attention in the emerging field of nanobiotechnology, thus being already exploited for the 35 preparation of biosensors, ${ }^{5}$ molecular transporters for drug, gene and protein delivery, ${ }^{6}$ and fuel-powered artificial muscles. ${ }^{7}$ In the area of tissue engineering, ${ }^{8-11}$ they have been extensively explored for bone regeneration ${ }^{12}$ and nerve tissue repair. ${ }^{13}$ In this context, a wide repertoire of methodologies has been explored 40 and optimized for the preparation of 2D CNT-based composites (e.g., films and fibers). ${ }^{3}$ However, the fabrication of $3 \mathrm{D}$ architectures has been more rarely accomplished, with some approaches including chitosan-based matrices, ${ }^{14-18}$ gelatin and/or methacrylate hydrogels ${ }^{19,20}$ or collagen scaffolds..$^{21}$ Furthermore, ${ }_{45}$ diverse polymeric systems have been exploited for CNT dispersion, such as poly(lactic-co-glycolic acid) ${ }^{22}$ or poly(methyl methacrylates). ${ }^{23}$

Nanomaterial-induced cytotoxicity has been related to size/mass, shape, surface charge, and functionalization, ${ }^{24}$ with 50 both size-dependent ${ }^{25}$ and composition-dependent ${ }^{26}$ toxicity mechanisms. In the particular case of CNTs, an increasing number of studies have focused on their use as "brick" elements of $2 \mathrm{D}$ and $3 \mathrm{D}$ materials envisioned for biomedical applications. ${ }^{27-}$ ${ }^{31}$ Nevertheless, the toxicity of CNTs remains controversial. ${ }^{32}$ In 55 order to bring some insights into the still uncertain interaction of 3D structures composed of CNTs with mammalian cells, we explored herein the interaction of three cell types (i.e., murine fibroblasts, human bone sarcoma cells and porcine endothelial progenitor cells) with MWCNT-based 3D scaffolds that showed ${ }_{60}$ different architectural and morphological features at the microscale. The introduction of MWCNTs in these structures not only allowed for the acquisition of $3 \mathrm{D}$ architectures, but also conferred superior mechanical properties and electrical conductivity to the resulting scaffolds. These matrices were ${ }_{65}$ obtained by the application of the ice segregation induced selfassembly (ISISA) process into MWCNT aqueous suspensions containing different polymers (i.e., chitosan, chondroitin sulphate and gelatin), that acted as dispersant agents. ${ }^{33}$ The chemical nature of every polymer contributed to the formation of a 70 particular patterned porous structure. ${ }^{34-36}$ Besides the use of different polymers, the scaffold structure was modified by the incorporation of two different types of functionalized MWCNTs 
(i.e., long MWCNTs and short MWCNTs; abbreviated as LN and $\mathrm{SN}$, respectively), as well as by the application of two different temperatures during the ISISA process (i.e., -196 and $-65{ }^{\circ} \mathrm{C}$ ). Cell-material interaction was assessed by studying cell viability, 5 adhesion, morphology, and apoptosis. Time-lapse confocal laser scanning microscopy was also used to explore, for the first time in CNT-based scaffolds, cell migration processes in real time.

\section{Results and Discussion}

\subsection{Scaffold characterization}

${ }_{10}$ CNT-based scaffolds displaying different architectural and morphological features were obtained by the application of the ISISA process, a simple and versatile bottom-up technique based on the unidirectional immersion of an aqueous solution, a colloidal suspension or even a hydrogel into a liquid nitrogen 15 bath and subsequent freeze-drying. This process has demonstrated its suitability for the preparation of inorganic, organic and hybrid macroporous monoliths and fibers. ${ }^{37-39}$ In this particular case, we applied the ISISA process to MWCNT aqueous suspensions that were prepared using different polymers 20 as dispersant agents. The polymers of choice were chitosan, ${ }^{40}$ chondroitin sulphate ${ }^{41,}{ }^{42}$ and gelatin, ${ }^{43}$ all well-known biocompatible polymers. For scaffold crosslinking, we used chemical agents that have been also extensively explored for the fabrication of biocompatible materials (e.g., glutaraldehyde and 25 hexamethylene diisocyanate). ${ }^{44,}{ }^{45}$ Besides the use of different polymers, the scaffold morphology was modified by the incorporation of two different types of MWCNTs. The first type, defined as $\mathrm{LN}$, was obtained upon acid treatment with $\mathrm{HNO}_{3}$ that resulted in MWCNT functionalization with carboxylic groups

30 without significant modification of their original length (i.e., 5-9 $\mu \mathrm{m})$. For the second type (i.e., SN), MWCNTs were exposed to a more aggressive acid treatment with a mixture of $\mathrm{HNO}_{3}$ and $\mathrm{H}_{2} \mathrm{SO}_{4}$ that not only promoted the functionalization with carboxylic groups, but also shortened their original length to ca. 3 $35 \mu \mathrm{m}$. The resulting six scaffolds (i.e., LNCHI, SNCHI, LNCHO, SNCHO, LNGEL, and SNGEL) exhibited a homogeneous structure throughout the entire monolith that differed depending on the particular polymer and MWCNTs used (Figure 1-SI). Thus, the use of $\mathrm{CHI}$ and $\mathrm{CHO}$ promoted the formation of 40 scaffolds with a well-patterned cross-section structure, whereas those scaffolds prepared from GEL suspensions exhibited a more disordered patterned-like one (Figure 1 and 2). We also prepared an additional type of LNCHI scaffolds where both the pore diameter and the width of the walls that support the porous 45 structure were modified by the application of the ISISA process at $-65^{\circ} \mathrm{C}$ (rather than $-196{ }^{\circ} \mathrm{C}$ ) (Figure 3). ${ }^{46}$ These scaffolds were abbreviated as LNCHI- 65 .

The morphology of the different scaffolds also differed in terms of porosity and surface roughness (Table 1). In regard to 50 porosity, we analyzed from SEM micrographs of cross-sectioned scaffolds the pore area per cross-sectioned area $\left(A_{P}\right)$ and the averaged pore width $\left(W_{P}\right)$. The most significant differences were found between LNCHI- 65 and the rest of scaffolds because of the well-known influence that the freezing temperature has on ${ }_{55}$ scaffold morphology. ${ }^{46}$ Nonetheless, $A_{P}$ and $W_{P}$ of scaffolds prepared at $-196{ }^{\circ} \mathrm{C}$ from different polymers also experienced a noticeable change, both parameters decreasing from $\mathrm{CHI}-$ to
CHO- up to GEL-based scaffolds. Finally, SN-type scaffolds also exhibited significant differences in both parameters as compared 60 to their respective LN-type analogues. Interestingly, $A_{P}$ increased for every SN-type scaffold whereas $W_{P}$ increased for SNCHI and SNCHO, but decreased for SNGEL.

Table 1. Scaffold characterization including porosity, surface roughness, 65 mechanical properties, and electrical conductivity.

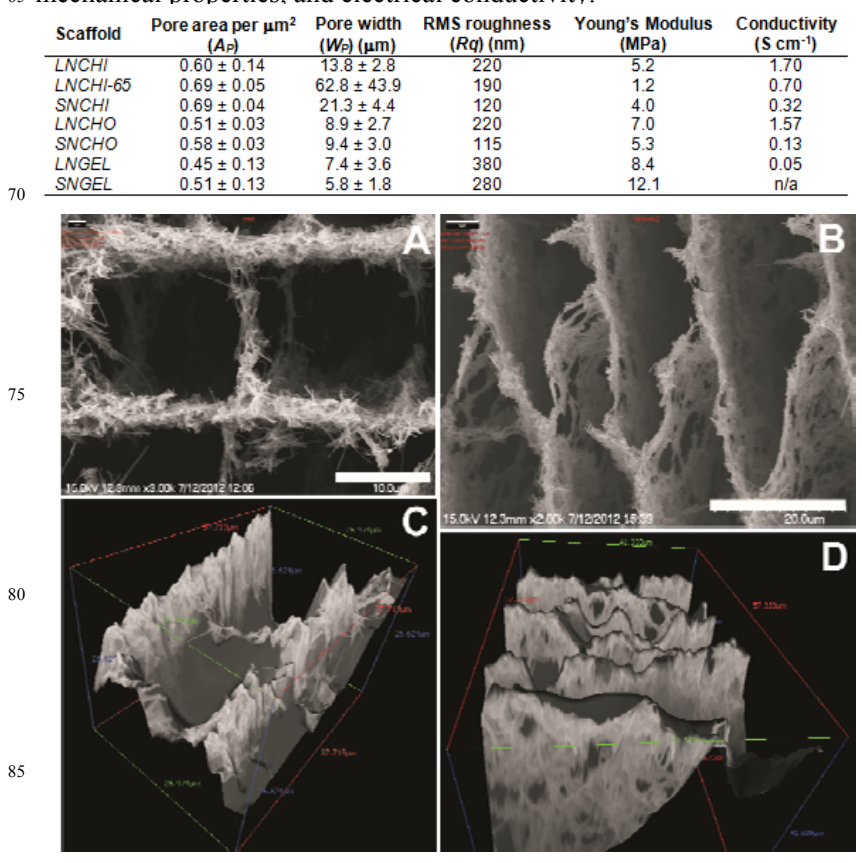

Figure 1. SEM images of LNCHI (A) and SNCHI (B) scaffolds, along 90 with their $3 \mathrm{D}$ reconstructed images (C and $\mathrm{D}$, respectively). Scale bars: 10 $\mu \mathrm{m}(\mathrm{A})$ and $20 \mu \mathrm{m}$ (B).

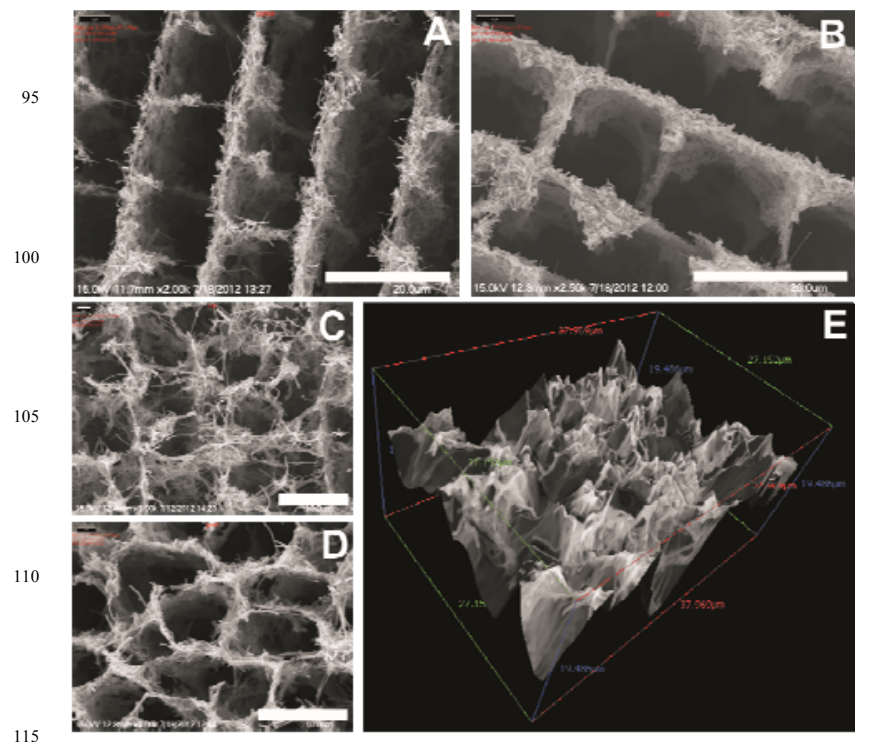

Figure 2. SEM images of LNCHO (A), SNCHO (B), LNGEL (C), and SNGEL (D). 3D reconstructed image from LNGEL (E). Scale bars: 20 $\mu \mathrm{m}(\mathrm{A}, \mathrm{B})$ and $10 \mu \mathrm{m}(\mathrm{C}, \mathrm{D})$.

120 When analyzing the roughness of the walls that define the cross-sectioned structures on which cells were cultured (Figure 1, 2 and 3, and Table 1), the root mean square (RMS) roughness increased from scaffolds with a well-patterned cross-section 
structure (i.e., $\mathrm{CHI}$ and $\mathrm{CHO}$ ) to those with a disordered one (i.e., GEL). This behavior was ascribed to both the dimensions of MWCNTs and their rigid nature, which determined a better accommodation of MWCNTs within the walls of LNCHI and ${ }_{5}$ LNCHO rather than on LNGEL scaffolds. The relevance of the dimensions of MWCNTs and their rigid nature on this parameter was corroborated on SN-type scaffolds. In this case, RMS roughness experienced a significant decrease in every scaffold because the use of shorter MWCNTs was obviously facilitating 10 their accommodation and the subsequent formation of more compact walls. Additionally, the dimensions of the walls also played a role as lower RMS roughness values were found in the thick walls of LNCHI-65 scaffolds than in the thinner ones of LNCHI.

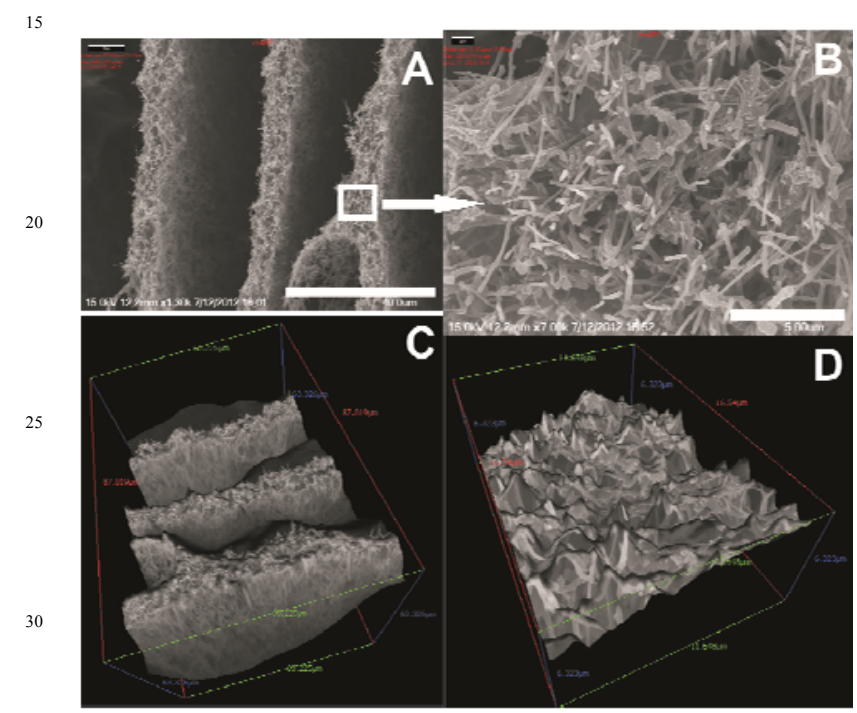

Figure 3. SEM images showing the macroporous structure of LNCHI-65 (A) and a detail of MWCNTs accommodating within scaffold walls (B). $353 \mathrm{D}$ reconstructed images from $(\mathrm{A})$ and $(\mathrm{B})$ are shown $(\mathrm{C}, \mathrm{D}$ respectively). Scale bars: $40 \mu \mathrm{m}(\mathrm{A})$ and $5 \mu \mathrm{m}$ (B).

Finally, the mechanical properties and conductivity of the different scaffolds were found strongly influenced by the above40 mentioned differences in architecture and morphology (Table 1). For instance, GEL-based scaffolds showed the highest Young modulus and the lowest conductivity likely because of a more deficient connection between MWCNTs in their poorly compacted walls.

\subsection{Cell type rationale and size considerations}

We first used murine L929 fibroblasts (Figure 4A-B) as a reference cell line for preliminary biocompatibility studies in vitro. ${ }^{47}$ They are considered slow-moving cells with a typically

50 elongated morphology in culture. Human Saos-2 osteoblasts were selected as a mature cell type displaying a more polygonal morphology in culture (Figure 4C-D) and previously used in the cytocompatibility assessment of CNT-based materials. ${ }^{28,} 29$ Finally, we explored the behavior of porcine endothelial cells 55 derived from peripheral blood progenitors $\left(\mathrm{EC}_{\mathrm{PC}}\right.$ cells), as previous studies have reported a higher susceptibility of some stem cells to CNT-induced cellular damage. ${ }^{48}$ Since their discovery by Asahara et al. in $1997,{ }^{49} \mathrm{EC}_{\mathrm{PC}}$ cells have already demonstrated an excellent therapeutic potential for diverse
60 applications, such as vascular repair and bone healing. ${ }^{50,51}$ Contrary to L929 fibroblasts and Saos-2 osteoblasts, $\mathrm{EC}_{\mathrm{PC}}$ cells are larger (both in length and width) and tend to spread on the substrate acquiring a pavement-like morphology to imitate the vascular endothelial lining (Figure 4E-F). Table 2 summarizes ${ }_{65}$ dimensions of the different cells used in this study. For comparative purposes, data were represented as the ratio between cell length and width $(l / w)$, so that elongated cells were characterized by higher $l / w$ ratios than rounded cells and vice versa. We assumed that the ability of the three different cell types 70 to initially colonize the scaffold was similar, as cells showed a comparable size when trypsinized.

Table 2. Size comparison among the different cell types used in these studies. Cell size was measured and averaged after either trypsin 75 treatment (in suspension) or culture for $48 \mathrm{~h}$ on TCP (adhered in culture). The ratio $l / w$ was calculated as cell length divided by cell width. Statistics: ${ }^{* * *} \mathrm{p}<0.005$.

\begin{tabular}{|c|c|c|c|}
\hline & L929 fibroblasts & Saos-2 osteoblasts & $\mathrm{EC}_{\mathrm{PC}}$ cells \\
\hline $\begin{array}{l}\text { In suspension } \\
\text { Diameter ( } \mu \mathrm{m})\end{array}$ & $5.2 \pm 0.69$ & $4.7 \pm 0.76$ & $5.5 \pm 1.01^{* * *}$ \\
\hline $\begin{array}{l}\text { Adhered in cultu } \\
\text { Length }(\mu \mathrm{m}) \\
\text { Width }(\mu \mathrm{m}) \\
\text { l/W ratio }\end{array}$ & $\begin{array}{c}16.0 \pm 3.87 \\
3.8 \pm 0.86 \\
4.2\end{array}$ & $\begin{array}{c}13.5 \pm 4.04 \\
4.7 \pm 1.37 \\
2.9\end{array}$ & $\begin{array}{c}24.6 \pm 7.12^{\star \star \star} \\
7.6 \pm 2.35^{\star \star \star} \\
3.2\end{array}$ \\
\hline
\end{tabular}

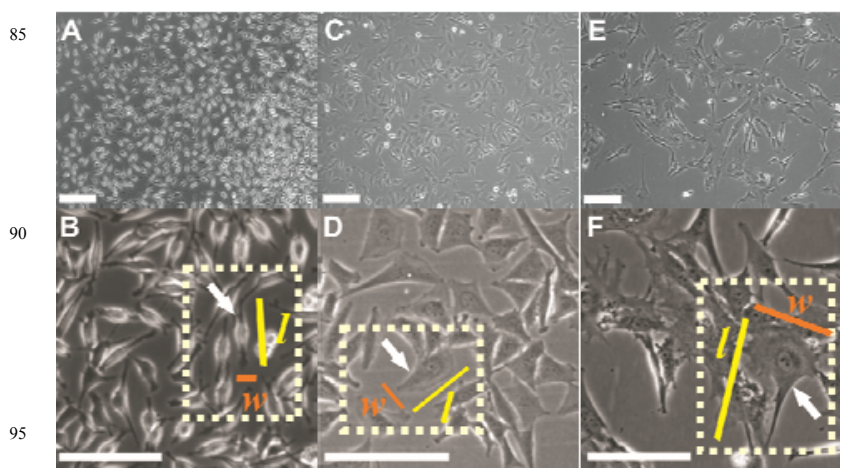

Figure 4. Light optical microscopy images of L929 fibroblasts (A, B), Saos-2 osteoblasts (C, D) and $\mathrm{EC}_{\mathrm{PC}}$ cells $(\mathrm{E}, \mathrm{F})$. Cell size was estimated from cell length $(l)$ and width $(w)$, as indicated in representative cells 100 (white arrows). Scale bars: $20 \mu \mathrm{m}$.

\subsection{Cell viability and apoptosis studies}

Cell viability was investigated on every scaffold for the three different cell types mentioned above. For this purpose, two 105 different probes were used simultaneously: calcein, for alive cells, and EthD-1, for dead cells. Initial studies with L929 fibroblasts revealed that cultures on LNCHI and LNCHO scaffolds exhibited superior viabilities than those on LNGEL (Figure 5 and Table 3). This behaviour could be ascribed to 110 either the presence of polymers with different chemical functionalities or to the different scaffold morphology. To discard the first hypothesis, control cultures were carried out on glass coverslips homogeneously coated with a thin crosslinked polymer layer of CHI, CHO or GEL (Figure 2-SI and Table 3). Cell 15 viability values on the three polymers were comparable to those obtained on tissue culture polystyrene (TCP, control surface) for the three cell types, thus confirming the absence of a relevant role played by polymer chemistry on this parameter. In consequence, we further focused on scaffold architecture and morphology as 
key responsible parameters for cell behavior. Interestingly, previous studies by Giannona et al. evidenced a significant influence of CNT organization on cell morphology, orientation and growth of osteoblast-like cells. ${ }^{52}$ For this purpose, L929 5 fibroblasts were seeded on LNCHI-65 scaffolds, which displayed significant architectural and morphological differences with respect to the rest of scaffolds. Cells on LNCHI were mostly suspended in the air occupying the pore space (Figure 5B), whereas those on LNCHI-65 spread on the thick walls that 10 characterize its structure (Figure 5D). However, despite the architectural differences between scaffolds, similar viability values were obtained.

Table 3. Cell viability on the different substrates. Statistically significant 15 differences $(\mathrm{p}<0.05)$ : (a) respect to TCP for a particular cell type, (b) between LN and SN for a particular scaffold and cell type and (c) among different cell types for a particular scaffold.

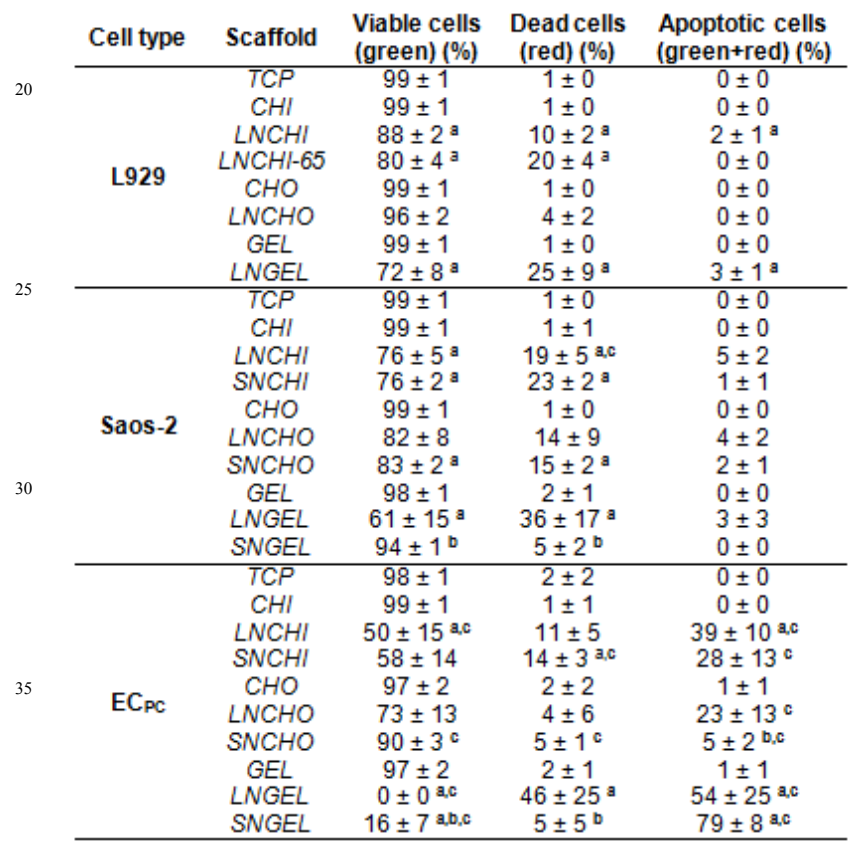

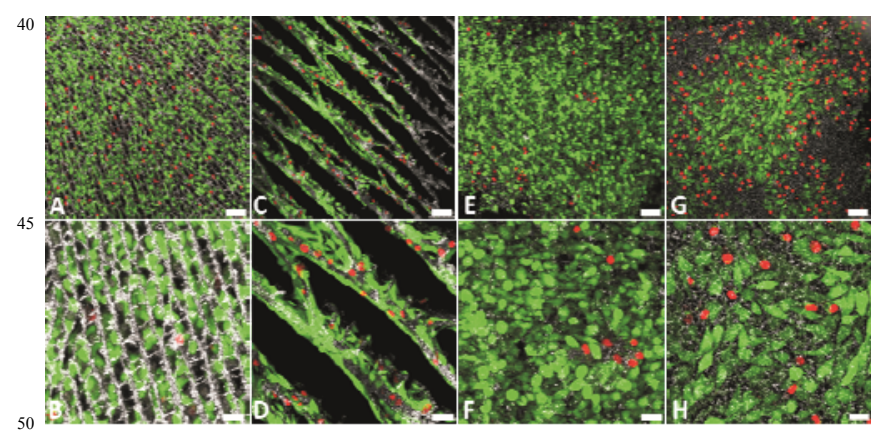

Figure 5. L929 fibroblast cell viability on LNCHI (A, B), LNCHI-65 (C, D), LNCHO (E, F), and LNGEL (G, H) scaffolds. Dead cells appear stained in red, while live cells stain in bright green. Representative culture images at $48 \mathrm{~h}$ are shown. Scale bars: $75 \mu \mathrm{m}$ (top) and $25 \mu \mathrm{m}$ (bottom).

The lack of conclusive results from L929 fibroblast cultures decided us to investigate the role of morphological scaffold features on the viability of more selective cell types (e.g., Saos-2 and $\mathrm{EC}_{\mathrm{PC}}$ cells). While some cytocompatibility studies of Saos-2 ${ }_{60}$ cells cultured on CNT-based scaffolds exist, ${ }^{28,}{ }^{29}$ the behavior of
$\mathrm{EC}_{\mathrm{PC}}$ cultures on this type of materials has not been explored yet. CLSM studies demonstrated a similar trend on the viability of Saos-2 cells than that described for L929 fibroblasts (i.e., $\mathrm{LNCHO}=\mathrm{LNCHI}>\mathrm{LNGEL})$. However, the viability of $\mathrm{EC}_{\mathrm{PC}}$ ${ }_{65}$ cells experienced a significant decrease, reaching a dramatic situation for LNGEL scaffolds, where negligible values of viable cells were found (Figure 6, 3-SI and 4-SI, and Table 3). A close inspection of these micrographs revealed a higher percentage of cells with double green/red fluorescence, likely attributed to

70 apoptotic cells, when $\mathrm{EC}_{\mathrm{PC}}$ cells were cultured on LNGEL. This result is not surprising, as cells respond differently depending on the structure of nanomaterials ${ }^{53}$ and CNTs have been described to induce apoptosis in several cell types. ${ }^{27}$ For instance, epidermal keratinocytes, a cell type with a spread adhesion pattern 75 comparable to that in $\mathrm{EC}_{\mathrm{PC}}$ cells, experienced oxidative stress and reduction in cell viability when exposed to MWCNTs. ${ }^{54}$ To further confirm this aspect, we analyzed the cellular externalization of phosphatidylserine by annexin- $\mathrm{V}$ binding on LNGEL (low viability) and LNCHI scaffolds (high viability)

80 (Figure 7). Saos-2 cells were also tested as a cell control with high viability. On $\mathrm{LNCHI}$, some $\mathrm{EC}_{\mathrm{PC}}$ cells were identified in early and late apoptotic stages (green and green/red fluorescence, respectively), as well as dead cells (red). On LNGEL, however, both $\mathrm{EC}_{\mathrm{PC}}$ cell death and apoptosis significantly increased, thus 85 confirming the reduction in cell viability previously observed. Contrary to results with $\mathrm{EC}_{\mathrm{PC}}$ cells, Saos-2 cell cultures showed negligible cell death (either necrotic or apoptotic) on LNCHI scaffolds and a majority of viable cells in LNGEL.

90

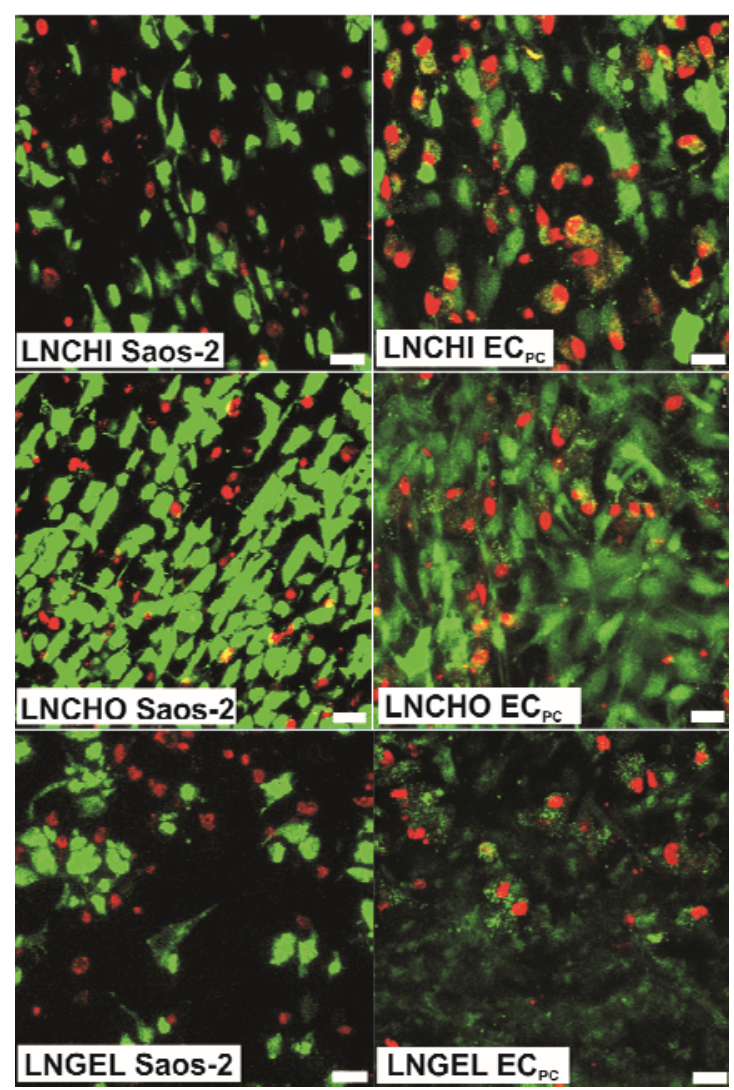

Figure 6. Cell viability of Saos-2 osteoblasts and $\mathrm{EC}_{\mathrm{PC}}$ cells on LNCHI, LNCHO and LNGEL scaffolds. Representative culture images at $48 \mathrm{~h}$ are shown. Scale bars: $25 \mu \mathrm{m}$. 


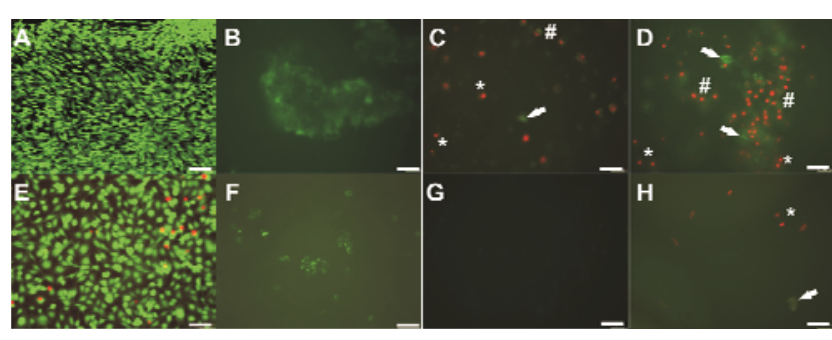

Figure 7. Apoptosis studies on $\mathrm{EC}_{\mathrm{PC}}(\mathrm{A}-\mathrm{D})$ and Saos-2 cells $(\mathrm{E}-\mathrm{H})$ cultured on LNCHI (C, G) or LNGEL scaffolds (D, H). Initial viability of the cultures was also confirmed (A, E). Incubation with $\mathrm{H}_{2} \mathrm{O}_{2}$ for $1 \mathrm{~h}$ was used as positive control for apoptosis induction (B, F). Early apoptotic cells expressing annexin- $\mathrm{V}$ were stained in green (white arrows), while dead cells were marked in red $\left(^{*}\right)$. Cells with double staining were indicative of cells experiencing late apoptosis (\#). Scale bars: $75 \mu \mathrm{m}$.

\section{2.4. Cell adhesion and morphology studies by SEM}

With the aim of identifying more precisely the parameter that was governing the difference in viability observed, the adhesion and colonization of the scaffold surface by Saos-2 osteoblasts and $\mathrm{EC}_{\mathrm{PC}}$ cells were studied by SEM (Figure 8). At first glance, the 15 presence of CNTs did not alter cell adhesion and morphology when compared to cultures on TCP (Figure 4) and thin polymer films (Figure 2-SI), as previously described for other CNT-based materials. ${ }^{55}$ Interestingly, as anticipated by CLSM studies (Figure 6), Saos-2 osteoblasts colonized LNCHI and LNCHO scaffolds 20 similarly to L929 fibroblasts, with cells mostly suspended in the air occupying pore spaces between scaffold walls. The comparable size of both cell types with the pore width allowed them to fit into the pores, thus minimizing the contact points between cell and substrate (Figure 8C). This was not the 25 situation for $\mathrm{EC}_{\mathrm{PC}}$ cells, whose larger size made them cover more than a single pore when forming a pavement-like monolayer that resembled native endothelialization of vascular conducts (Figure 8D and 8E). As compared to L929 and Saos-2 cells, the innate adhesion pattern of $\mathrm{EC}_{\mathrm{PC}}$ cells led to increase their contact 30 surface with the scaffold. This situation was stressed for cultures on LNGEL, where its narrower pores (Figure 2 and Table 1) forced $\mathrm{EC}_{\mathrm{PC}}$ cells to spread across a larger number of pores (Figure 8F and 8I).

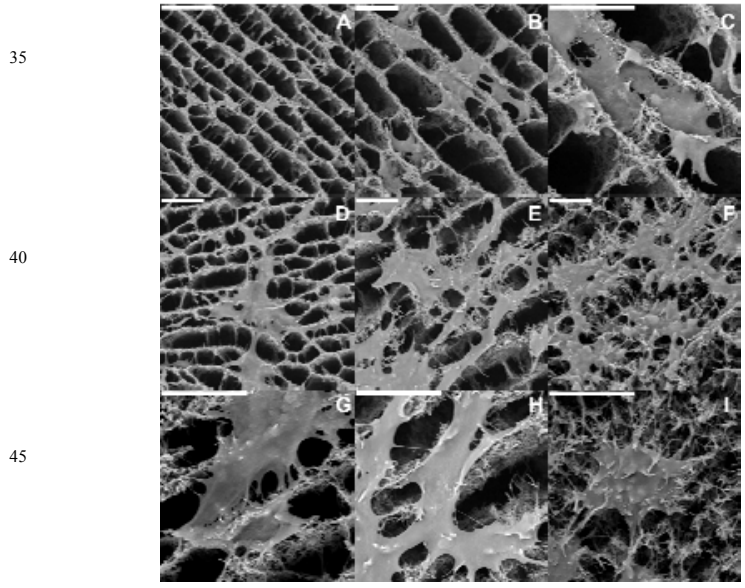

Figure 8. Cell adhesion and morphology of Saos-2 osteoblasts on LNCHI $50(\mathrm{~A}-\mathrm{C})$ and porcine $\mathrm{EC}_{\mathrm{PC}}$ cells on $\mathrm{LNCHI}(\mathrm{D}, \mathrm{G}), \mathrm{LNCHO}(\mathrm{E}, \mathrm{H})$ and LNGEL (F, I). Representative 48-h culture images are shown. Scale bars: $50 \mu \mathrm{m}(\mathrm{A})$ and $20 \mu \mathrm{m}(\mathrm{B}-\mathrm{I})$.
However, the great deal of cell harm caused by LNGEL 55 scaffolds is difficult to justify only in terms of contact surface. At this stage, one should consider that also roughness has to play a role in cell damage. Thus, the reduced and negligible viability found in LNGEL (for Saos-2 and $\mathrm{EC}_{\mathrm{PC}}$ cells, respectively) could be ascribed not only to the increase in contact surface, but also to 60 its roughness, much higher than in any of the other scaffolds (Table 1). This issue was actually corroborated by the viability enhancement observed in all SN-type scaffolds when compared to their LN counterparts (Figure 9). Particularly insightful was the case of $\mathrm{EC}_{\mathrm{PC}}$ cells cultured on SN-type scaffolds where, as ${ }_{65}$ compared to LN-type ones, the decrease in RMS roughness was accompanied by a significant increase in the percentage of viable cells (Figure 9F, Table 3). Unfortunately, in the particular case of SNGEL scaffolds and while recognizing the achievement of a neat viability improvement, this was not sufficient to support 70 adequate $\mathrm{EC}_{\mathrm{PC}}$ cell viability and makes questionable the use of these scaffolds for $\mathrm{EC}_{\mathrm{PC}}$ cell growth. Finally, it is worth noting that SNCHI scaffolds not only exhibited a decrease in RMS roughness, but also an increase in $A_{P}$ and $W_{P}$ that might also benefit cell viability. In any case, a similar cell viability 75 improvement was also observed in SNCHO, where changes in $A_{P}$ and $W_{P}$ were negligible when compared to $\mathrm{LNCHO}$, thus confirming roughness as a critical parameter for cell damage.

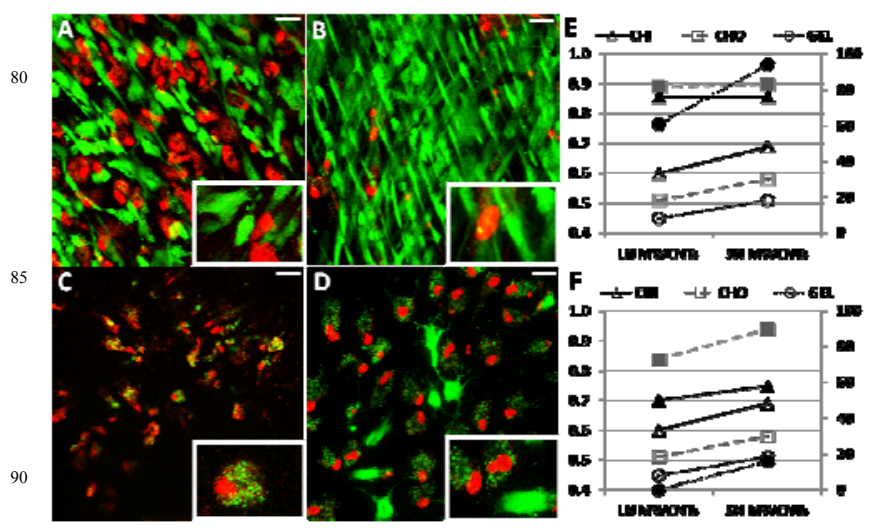

Figure 9. Cell viability of $\mathrm{EC}_{\mathrm{PC}}$ cells cultured on $\mathrm{LNCHO}(\mathrm{A}), \mathrm{SNCHO}$ (B), LNGEL (C), and SNGEL (D) scaffolds. Details of stained cells are included as insets. Representative 48-h culture images are shown. Scale 95 bars: $25 \mu \mathrm{m}$. (E, F) Simultaneous increase in scaffold pore area per $\mu \mathrm{m}^{2}$ (open labels, left $\mathrm{Y}$ axe) and cell viability (filled labels, right $\mathrm{Y}$ axe) induced by the use of $\mathrm{SN}$ in Saos-2 (E) and $\mathrm{EC}_{\mathrm{PC}}(\mathrm{F})$ cell cultures.

\subsection{Cell migration studies by time-lapse CLSM recording}

100 Finally, we hypothesized that the visualization of the early cellmaterial interaction would provide evidence of cell movements for scaffold colonization and further corroborate the relevance of porosity, roughness and contact surface on material cytocompatibility. Time-lapse recording is a powerful technique 105 recently applied for this purpose. ${ }^{56}$ However, and despite its potential, it has been rarely used for the exploration of cell behavior on $3 \mathrm{D}$ matrices $^{57,58}$ and no reports exist to date on the application of this technique to evaluate cell interactions with CNT-based substrates. Herein, we report for the first time the use 110 of time-lapse CLSM to visualize migration of human Saos- 2 cells 
on 3D CNT-based scaffolds. For these studies, LNCHI, SNCHI and LNGEL scaffolds were selected as representative of the different architectures and morphologies investigated in this work (Figure 5-SI and Movie 1, 2 and $\mathbf{3}$ in supplementary data). TCP 5 was used as a control surface (bottom panel in Figure 5-SI). As shown in the recordings, Saos- 2 cells exhibited not only a well spread morphology once adhered to the substrates, but also an evident motility that exploited in the exploration of the scaffold surface. Interestingly, cells on LNCHI and SNCHI scaffolds 10 seemed to move more actively than those on LNGEL or TCP, where cell displacements slightly diminished. Particularly, cell movements were more evidently appreciated in SNCHI. According to this, Aoki et al. also observed a strikingly extended morphology of Saos-2 cells when in culture on CNT-containing 15 polycarbonate scaffolds, ${ }^{29}$ probably attributed to an enhanced protein adsorption driven by the inherent adsorptive properties of CNTs. The biocompatible polymers used herein for CNT dispersion and scaffold fabrication likely contributed to this favored cell adhesion and motility, as Mwenifumbo et al. 20 observed a rounded morphology in Saos- 2 cells when cultured on plain nano-structured MWCNT-based constructs. ${ }^{28}$ From a molecular perspective, this higher cell motility could be related to CNT-induced effects on the expression of the focal adhesion kinase (FAK), actively implicated in cytoskeleton organization, 25 migration and proliferation, ${ }^{59}$ as previously observed in HeLa cells on non-oriented CNT-based scaffolds. ${ }^{27}$ We hypothesize that these movements described by the cells in order to find proper adhesion locations further contributed to the induction of cell damage on those scaffolds where contact surface and 30 roughness were enhanced.

\section{Experimental}

\subsection{Materials}

Chemical reagents were purchased from Sigma-Aldrich and used as received unless otherwise indicated. For scaffold preparation,

35 low molecular weight chitosan, chondroitin sulphate, gelatin, and MWCNTs (110-170 $\mathrm{nm}$ in diameter, 5-9 $\mu \mathrm{m}$ in length) were used. Cell culture media and supplements were purchased from Lonza.

3.2. Purification and chemical functionalization of MWCNTs 40 MWCNTs were purified and functionalized by acidic treatment with $\mathrm{HNO}_{3}$ at $130{ }^{\circ} \mathrm{C}$ for $5 \mathrm{~h}$. After cooling at room temperature, the suspension was filtered by using cellulose filters $(0.2 \mu \mathrm{m}$ pore size) and washed in distilled water to eliminate any acidic residues. MWCNTs were then freeze-dried and stored until used.

${ }_{45}$ The so obtained MWCNTs were named as long MWCNTs (LN).

The short MWCNTs (SN) were obtained by exposure of LN to a stronger acidic treatment with $\mathrm{H}_{2} \mathrm{SO}_{4}$ and $\mathrm{HNO}_{3}$.

\subsection{Preparation of cross-linked CNT-based scaffolds}

Chitosan/MWCNT cross-linked scaffolds were prepared by using ${ }_{50}$ the ISISA process as previously described. ${ }^{15,35}$ Briefly, either LN or SN MWCNTs were dispersed in chitosan solutions ( $1 \mathrm{wt} \%$ in acetic acid $0.15 \mathrm{M}, \mathrm{pH} 4.5)$. The suspension was then collected into insulin syringes $(1 \mathrm{ml})$ and two different freezing ISISA methodologies were applied in order to modify the scaffold 55 channel dimensions: constant dipping rate of $5.9 \mathrm{~mm} \mathrm{~min}^{-1}$ at $196{ }^{\circ} \mathrm{C}$ (liquid nitrogen) or $0.9 \mathrm{~mm} \min ^{-1}$ at $-65^{\circ} \mathrm{C}$ (dry ice). The resulting monoliths were additionally exposed to glutaraldehyde vapors (GA, $50 \mathrm{wt} \%$ in distilled water) at room temperature for $24 \mathrm{~h}$ to obtain structure reinforcement by chitosan crosslinking. ${ }_{60}$ Finally, the so obtained scaffolds (LNCHI and SNCHI, containing either long or short MWCNTs, respectively) were aerated for $24 \mathrm{~h}$. A similar methodology was used for the fabrication of CNT-based scaffolds made of either chondroitin sulphate (CHO) or gelatin (GEL) with the exception that scaffold ${ }_{65}$ crosslinking was achieved by exposure to hexamethylene diisocyanate (HMDI) vapors at $37{ }^{\circ} \mathrm{C}$ for 7 days. The so obtained scaffolds (LNCHO and SNCHO for chondroitin sulphate; LNGEL and SNGEL for gelatin) were also aerated for further 24 $\mathrm{h}$ before use. Singular scaffolds were obtained from freeze-dried 70 monoliths by cryo-fracture.

\subsection{Preparation of polymer-coated glass coverslips}

Solutions of CHI $(2 \% \mathrm{w} / \mathrm{v}$ in acetic acid $)$, CHO $(6 \% \mathrm{w} / \mathrm{v}$ in distilled water) and GEL ( $2 \% \mathrm{w} / \mathrm{v}$ in distilled water) were used to homogeneously coat circular glass coverslips by spin-coating, 75 followed by polymer crosslinking with GA or HMDI.

\subsection{Scaffold characterization}

Details of scaffold architecture, cross-section morphology and pore size were examined by using a DSM-950 scanning electron microscope (SEM, Zeiss). Scaffold porosity was measured from ${ }_{80}$ SEM images by using the UTHSCSA ImageTool software. Porosity was expressed as pore area per $\mu \mathrm{m}^{2}\left(A_{P}\right)$ and pore width $\left(W_{P}\right)$. Additional SEM micrographs were acquired in a Hitachi S4700 scanning electron microscope equipped with the MeX software package for $3 \mathrm{D}$ data acquisition and object 85 reconstruction using stereo-photogrammetry. The root mean square (RMS) roughness $(R q)$ was obtained from the reconstructed $3 \mathrm{D}$ model of the different specimens for a path lenght of $15 \mu \mathrm{m}$. The mechanical properties of the different scaffolds were measured at room temperature by using a Perkin90 Elmer DMA7 equipment, as previously described. ${ }^{60}$ Scaffold conductivity was measured by using a four-point method. ${ }^{61}$

\subsection{Cell culture}

Prior to cell culture, scaffolds (ca. $4.5 \mathrm{~mm}$ in diameter, ca. $3 \mathrm{~mm}$ in thickness) were sterilized under UV radiation for $20 \mathrm{~min}$ per 95 side and preconditioned in culture medium for $24 \mathrm{~h}$ to eliminate any toxic residues from the synthesis. Three different cell types were tested: murine L929 fibroblasts, human osteoblast-like Saos-2 cells and porcine endothelial cells derived from peripheral blood progenitors $\left(\mathrm{EC}_{\mathrm{PC}}\right)$, obtained as previously described. ${ }^{62} \mathrm{~A}$ 100 total of $10^{5}$ cells was seeded on the top part of the scaffolds. DMEM supplemented with fetal bovine serum (10\%), streptomycin (100 UI ml $\mathrm{m}^{-1}$ ), penicillin (100 UI ml ${ }^{-1}$ ), and Lglutamine $(1 \mathrm{mM})$ was used for fibroblasts and osteoblasts and EGM-2 media for $\mathrm{EC}_{\mathrm{PC}}$ cells. Cultures were maintained in static 105 conditions at $37{ }^{\circ} \mathrm{C}$ in a sterile incubator under a $\mathrm{CO}_{2}(5 \%)$ atmosphere and visualized by using an Axiovert CFL-40 optical microscope when possible. Tissue culture polystyrene (TCP) was used as a control surface.

For cell size comparison, and assuming cells as entities with an 110 ellipsoidal shape for simplification, cell dimensions were expressed as $l / w$ ratios, where $l$ is the cell length (i.e., the longest cell dimension) and $w$ the cell width (i.e., the shortest dimension). In this sense, the higher the value of the $l / w$ ratio is, the more elongated the cell morphology is; whereas a $l / w$ ratio close to the 115 unitary value correlates with a more square cell shape. According 
to this, cell size was measured and averaged from at least 25 cells from each cell type either right after trypsin treatment or after culture on TCP.

\subsection{Viability and apoptosis studies}

5 To test cell viability, cells cultured on the different substrates were analyzed by using a Live/Dead $\AA$ Viability kit (Invitrogen), based on the use of two probes: calcein and ethidium homodimer1 (EthD-1). Samples were visualized by using a Leica SP5 confocal laser scanning microscope. The fluorescence of both 10 probes was excited by an Argon laser tuning to $488 \mathrm{~nm}$ and measured at $505-570 \mathrm{~nm}$ for green fluorescence (calcein) and 630-750 nm for red fluorescence (EthD-1). Physical reflexion from the scaffolds after excitation at $488 \mathrm{~nm}$ was also recorded to visualize the scaffold structure and the relative cellular location.

${ }_{15}$ To quantify cell viability, the number of live (green), dead (red) and apoptotic (green and red) cells were counted from $20 \mathrm{x}$ images.

Apoptotic cells in the cultures were specifically detected by using an annexin V-FITC apoptosis detection kit (Sigma). ${ }_{20}$ Simultaneous staining with the probe EthD-1 allowed for the discrimination among early apoptotic (green fluorescence), late apoptotic (green and red) and dead cells (red). Stained cells were then visualized by using a Leica DMI 6000B fluorescence microscope. Positive controls were obtained after cell treatment 25 with $\mathrm{H}_{2} \mathrm{O}_{2}$ (1 mM in PBS) for 90 min.

\subsection{Cell adhesion and morphology studies by SEM}

Cells cultured on the scaffolds for $48 \mathrm{~h}$ were examined by using a DSM-950 scanning electron microscope (Zeiss).

3.9. Time-lapse confocal laser scanning microscopy (CLSM)

${ }_{30}$ Cell migration on the different scaffolds was investigated by using time-lapse CLSM recording. Due to the opacity of CNTbased scaffolds, cells were labeled to allow their visualization with alexa fluor ${ }^{\circledR}$ 594-conjugated wheat germ agglutinin (WGA, $5 \mu \mathrm{g} \mathrm{ml}^{-1}$ in PBS, Invitrogen). After 5 minutes of incubation at 35 room temperature, cell movements were recorded for at least 3 hours by using a Leica SP5 confocal laser scanning microscope with an acclimatized chamber $\left(37^{\circ} \mathrm{C}, 5 \% \mathrm{CO}_{2}\right)$.

\subsection{Statistics}

Values were expressed as mean \pm standard deviation. Statistical 40 analysis was performed using the Statistical Package for the Social Sciences software (SPSS). Comparisons were done by analysis of variance (3 or more groups) or $\mathrm{t}$ Student (for 2 groups). In all cases, $\mathrm{p}<0.05$ was considered statistically significant.

\section{${ }_{45}$ Conclusions}

Herein we explored the interaction of three types of mammalian cells with MWCNT-based 3D scaffolds that showed different architectural and morphological features at the microscale. Figure 10 summarizes the different scenarios reported in this 50 work. Particularly, scaffolds displaying both a pore size in range with that of cells and lower surface roughness revealed the highest viability values (e.g., SNCHO). On the contrary, those with a smaller pore size and higher surface roughness accounted for the lowest cytocompatibility (e.g., LNGEL). These dramatic ${ }_{55}$ differences in cell viability found among scaffolds evidenced both material- and cell-dependent parameters as responsible for an adequate cell-material interaction, thus making a case-by-case study necessary. As a general trend, minimizing both the contact points between cell and substrate and the roughness of this ${ }_{60}$ contact surface provides evident benefits on cell viability. In this sense, $\mathrm{CHI}$ and $\mathrm{CHO}$ scaffolds were presented as more favorable substrates for cell growth. Additionally, we reported for the first time highly viable cultures of $\mathrm{EC}_{\mathrm{PC}}$ cells on $3 \mathrm{D}$ CNT-based scaffolds, thus opening their application in stem cell research as ${ }_{65}$ previously evidenced for other types of progenitor cells. ${ }^{13,63}$ Results from these studies bring novel insights into the still uncertain biological reactivity of CNT-based materials and benefit the fabrication of optimized biomaterials by varying scaffold-dependent parameters in accordance to those of target 70 cells.

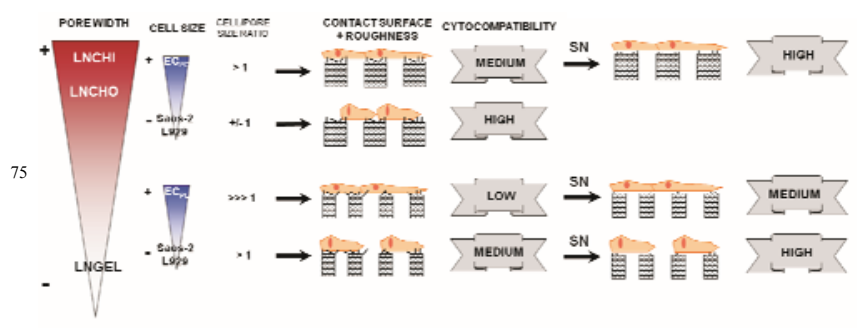

80 Figure 10. Scheme summarizing the correlation between scaffold- and cell-dependent parameters in the overall cytocompatibility of MWCNTbased 3D scaffolds.

\section{Notes and references}

Acknowledgements: This work was supported by MINECO ${ }_{85}$ (projects MAT2009-10214, MAT2011-25329, PIE 201060I017, and MAT2012-34811) and from the European Union Seventh Framework Programme (FP7/2007-2013) under grant agreement number 263289 (Green Nano Mesh). S.N. acknowledges CSIC for a JAE-Pre fellowship. M.C.S. is greatly in debt with 90 MINECO for a Juan de la Cierva fellowship. The authors thank Dr M.T. Portolés for the generous gift of L929 fibroblasts and Saos-2 osteoblasts. Fernando Pinto (from the Instituto de Ciencias Agrarias, CSIC), Sylvia Gutiérrez and Susana Hernández (from the Centro Nacional de Biotecnología, CSIC) 95 are respectively acknowledged for their assistance with SEM and CLSM studies, E. Timmins for her kind assistance with SEM equipment and 3D reconstruction images, A. Espinha for his help with the ImageTool software, and R. Jiménez for his technical support for scaffold mechanical and electrical characterization.

100

${ }^{a}$ Instituto de Ciencia de Materiales de Madrid (ICMM), Consejo

Superior de Investigaciones Científicas (CSIC), Calle Sor Juana Inés de la Cruz 3, 28049-Madrid, Spain. Fax: (+34) 91 3720623; Tel: (+34) 91 3349000; E-mail: conchi.serrano@icmm.csic.es, delmonte@icmm.csic.es

$\dagger$ Electronic Supplementary Information (ESI) available: [Additional details about the experimental part are included in the supplementary data]. See DOI: 10.1039/b000000x/

1101 S. Iijima, Nature, 1991, 354, 56.

2 M. Monthioux, V. L. Kuznetsov, Carbon, 2006, 44, 1621.

3 M. T. Byrne, Y. K. Gun'ko, Adv. Mater., 2010, 22, 1672.

4 J. N. Coleman, U. Khan, Y. K. Gun'ko, Adv. Mater., 2006, 18, 689.

5 K. Besteman, J. O. Lee, F. G. M. Wiertz, H. A. Heering, C. Dekker, Nano Lett., 2003, 3, 727.

6 N. W. S. Kam, M. O’Connell, J. A. Wisdom, H. Dai, Proc. Natl. Acad. Sci. USA, 2005, 102, 11600. 
7 V. H. Ebron, Z. Yang, D. J. Seyer, M. E. Kozlov, J. Oh, H. Xie, et al., Science, 2006, 311, 1580.

8 J. V. Veetil and K. Ye, Biotechnol. Prog., 2009, 25, 709.

9 P. A. Tran, L. Zhang and T. J. Webster, Adv. Drug Delivery. Rev., 2009, 61, 1097.

10 B. S. Harrison and A. Atala, Biomaterials, 2007, 28, 344

11 A. Bianco, K. Kostarelos, C. D. Partidos, M. Prato, Chem. Commun., $2005,5,571$

12 T. R. Nayak, L. Jian, L. C. Phua, H. K. Ho, Y. Ren, G. Pastorin, ACS Nano, 2010, 4, 7717

13 E. Jan and N. A. Kotov, Nano Lett., 2007, 7, 1123.

14 I. Olivas-Armendáriz, P. García-Casillas, R. Martínez-Sánchez, A. Martínez-Villafañe, C. A. Martínez-Pérez, J. Alloys Compounds, 2010, 495, 592.

1515 A. Abarrategi, M. C. Gutiérrez, C. Moreno-Vicente, M. J. Hortigüela, V. Ramos, J. L. López-Lacomba, et al., Biomaterials, 2008, 29, 94.

16 C. Lau, M. J. Cooney and P. Atanassov, Langmuir, 2008, 24, 7004.

17 M. J. Hortigüela, M. C. Gutiérrez, I. Aranaz, M. Jobbágy, A Abarrategi, C. Moreno-Vicente, et al., J. Mater. Chem., 2008, 18, 5933.

18 S. Nardecchia, M. C. Serrano, M. C. Gutiérrez, M. T. Portolés, M. L. Ferrer, F. del Monte, Adv. Funct. Mater., 2012, 22, 4411.

19 S. R. Shin, H. Bae, J. M. Cha, J. Y. Mun, Y. C. Chen, H. Tekin, et al., ACS Nano, 2012, 6, 362.

2520 J. Zou, J. Liu, A. S. Karakoti, A. Kumar, D. Joung, Q. Li, et al., ACS Nano, 2010, 4, 7293

21 E. Hirata, M. Uo, H. Takita, T. Akasaka, F. Watari, A. Yokoyama, Carbon, 2011, 49, 3284.

22 H. Zhang and Z. J. Chen, Bioactive Compatible Polym., 2010, 25, 241.

23 K. Rege, N. R. Raravikar, D. Y. Kim, L. S. Schadler, P. M. Ajayan, J. S. Dordick, Nano Lett., 2003, 3, 829.

24 L. Ding, J. Stilwell, T. Zhang, O. Elboudwarej, H. Jiang, J. P. Selegue, et al., Nano Lett., 2005, 5, 2448.

3525 V. M. Silva, N. Corson, A. Elder, G. Oberdorster, Toxicol. Sci., 2005, 85, 983

26 C. M. Sayes, J. D. Fortner, W. Guo, D. Lyon, A. M. Boyd, K. D. Ausman, et al., Nano Lett., 2004, 4, 1881.

27 X. Zhang, X. Wang, Q. Lu, C. Fu, Carbon, 2008, 46, 453.

4028 S. Mwenifumbo, M. S. Shaffer and M. M. Stevens, J. Mater. Chem., 2007, 17, 1894.

29 N. Aoki, A. Yokoyama, Y. Nodasaka, T. Akasaka, M. Uo, Y. Sato, et al., Chem. Lett., 2006, 35, 508.

30 T. J. Webster, M. C. Waid, J. L. McKenzie, R. L. Price, J. U. Ejiofor, Nanotechnology, 2004, 15, 48.

31 M. A. Correa-Duarte, N. Wagner, J. Rojas-Chapana, C. Morsczeck, M. Thie, M. Giersig, Nano Lett., 2004, 4, 2233.

32 H. F. Cui, S. K. Vashist, K. Al-Rubeaan, J. H. T. Luong, F. S. Sheu, Chem. Res. Toxicol., 2010, 23, 1131.

5033 S. Nardecchia, D. Carriazo, M. L. Ferrer, M. C. Gutiérrez, F. del Monte, Chem. Soc. Rev., 2013, 42, 794.

34 M. C. Gutiérrez, M. L. Ferrer and F. del Monte, Chem. Mater., 2008 , 20, 634 .

35 M. J. Hortigüela, I. Aranaz, M. C. Gutiérrez, M. L. Ferrer, F. del Monte, Biomacromolecules, 2011, 12, 179.

36 H. Zhang, I. Hussain, M. Brust, M. F. Butler, S. P. Rannard, A. I. Cooper, Nat. Mater., 2005, 4, 787.

37 M. C. Gutiérrez, M. Jobbágy, N. Rapún, M. L. Ferrer, F. del Monte, Adv. Mater., 2006, 18, 1137.

6038 S. Deville, E. Saiz, R. K. Nalla, A. P. Tomsia, Science, 2006, 311 515.

39 S. R. Mukai, H. Nishihara and H. Tamon, Chem. Commun., 2004, 10 874.

40 M. Dash, F. Chiellini, R. M. Ottenbrite, E. Chiellini, Progress Polym. 65 Sci., 2011, 36, 981

41 A. D. Baldwin and K. L. Kiick, Peptide Science, 2010, 94, 128

42 D. J. Mooney and E. A. Silva, Nature Mater., 2007, 6, 327.

43 K. Ulubayram, E. Aksu, S. I. D. Gurhan, K. Serbetci, N. Hasirci, J. Biomater Sci. Polym. Ed., 2002, 13, 1203.

7044 J. Berger, M. Reist, J. M. Mayer, O. Felt, N. A. Peppas, R. Gurny, Eur. J. Pharm. Biopharm., 2004, 57, 19.
45 W. Cao, M. Cheng, Q. Ao, Y. Gong, N. Zhao, X. Zhang, J. Biomater. Sci. Polymer Edn., 2005, 16, 791.

46 H. Nishihara, S. Iwamura and T. Kyotani, J. Mater. Chem., 2008, 18, 3662.

47 M. C. Serrano, R. Pagani, M. Vallet-Regí, J. Peña, A. Rámila, I. Izquierdo, et al., Biomaterials, 2004, 25, 5603.

48 L. Zhu, D. W. Chang, L. Dai, Y. Hong, Nano Lett., 2007, 7, 3592

49 T. Asahara, T. Murohara, A. Sullivan, M. Silver, R. van der Zee, T. Li, et al., Science, 1997, 27, 964

50 A. Zampetaki, J. P. Kirton and Q. Xu, Cardiovasc. Res., 2008, 78, 413

51 T. Matsumoto, R. Kuroda, Y. Mifune, A. Kawamoto, T. Shoji, M. Miwa, et al., Bone, 2008, 43, 434.

8552 S. Giannona, I. Firkowska, J. Rojas-Chapana, M. Giersig, J. Nanosci. Nanotechnol., 2007, 7, 1679

53 L. Ding, J. Stilwell, T. Zhang, O. Elboudwarej, H. Jiang, J. P. Selegue, et al., Nano Lett., 2005, 5, 2448.

54 A. Shvedova, V. Castranova, E. R. Kisin, D. Schwegler-Berry, A. R. Murray, V. Z. Gandelsman, et al., J. Toxicol. Environ. Health Part A., 2003, 66, 1909

55 R. A. MacDonald, B. F. Laurenzi, G. Viswanathan, P. M. Ajayan, J. P. Stegemann, J. Biomed. Mater. Res. A, 2005, 74, 489.

56 R. Gatti, G. Orlandini, J. Uggeri, S. Belletti, C. Galli, M. Raspanti, et al., Micron, 2008, 39, 137 .

57 T. A. Ulrich, A. Jain, K. Tanner, J. L. MacKay, S. Kumar, Biomaterials, 2010, 31, 1875.

58 G. P. Raeber, M. P. Lutolf and J. A. Hubbell, Acta Biomater., 2007, 3, 615 .

10059 J. T. Parsons, K. H. Martin, J. K. Slack, J. M. Taylor, S. A. Weed, Oncogene, 2000, 19, 5606

60 M. C. Serrano, M. C. Gutiérrez, R. Jiménez, M. L. Ferrer, F. del Monte, Chem. Commun., 2012, 48, 579.

61 M. C. Gutiérrez, D. Carriazo, A. Tamayo, R. Jiménez, F. Picó, J. M. Rojo, et al., Chem. A Eur. J., 2011, 17, 10537.

62 J Allen, S. Khan, M. C. Serrano, G. Ameer, Tissue Eng., 2008, 14 183.

63 S. Y. Park, S. Namgung, B. Kim, J. Im, J. Y. Kim, K. Sun, et al., Adv. Mater., 2007, 19, 2530. 


\section{Graphical Abstract}

Carbon nanotubes (CNT) are acquiring a tremendous impact as structural and functional components of biomaterials. Herein, we extensively explore the influence of architectural/morphological features and cell-dependent parameters on the cytocompatibility in vitro of 3D CNT-based scaffolds to benefit their optimization as cell growth platforms.

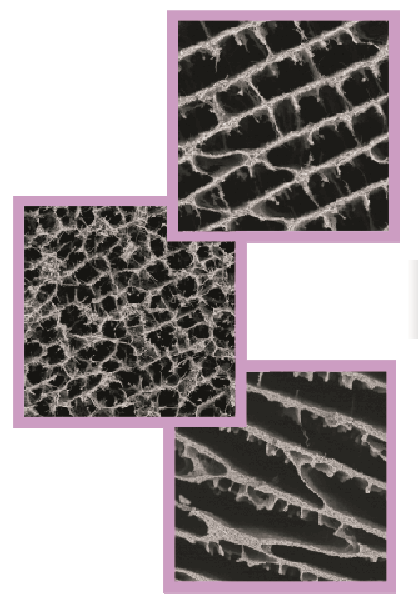

Diverse architecture and morphology

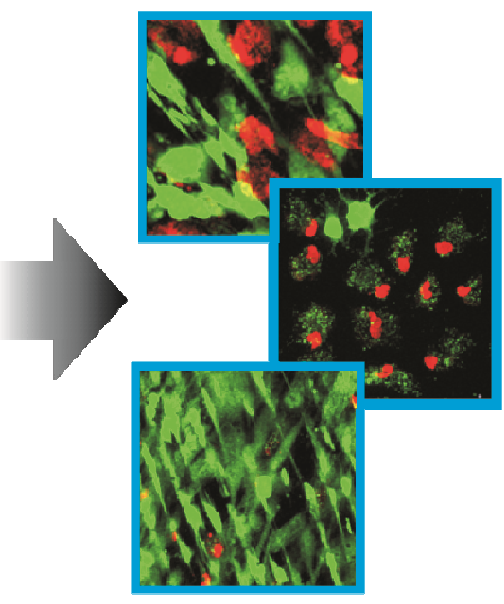

Diverse cell response

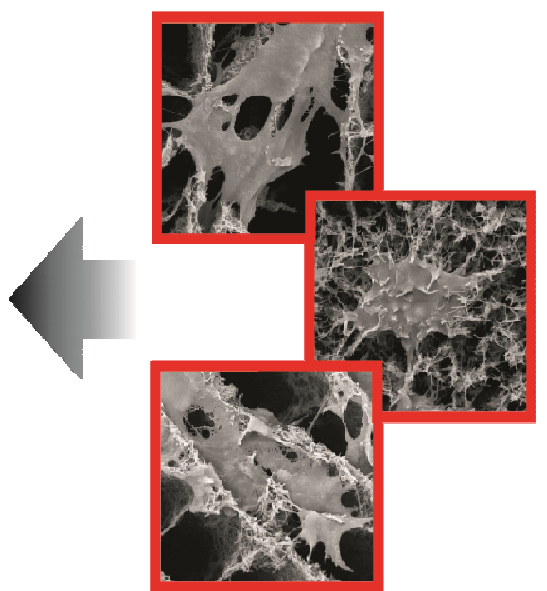

Diverse cell size and adhesion 


\section{SUPPORTING INFORMATION}

\section{Modulating the cytocompatibility of tridimensional carbon nanotube-based scaffolds}

Stefania Nardecchia, María Concepción Serrano*, María Concepción Gutiérrez, María Luisa Ferrer, and Francisco del Monte $\mathrm{F}^{*}$

\section{Materials and Methods (extended version)}

\section{Materials}

Chemical reagents were purchased from Sigma-Aldrich and used as received unless otherwise indicated. For scaffold preparation, low molecular weight chitosan (Batch\#06513AE, Brookfield viscosity 20000 cps), chondroitin sulphate (Batch\#STBB3576, bovine trachea), gelatin (Batch\#1189632-52205137, porcine skin), and MWCNTs (reference number 659258, 110-170 nm in diameter, 5-9 $\mu \mathrm{m}$ in length, according to manufacturer specifications) were used. Cell culture media and supplements were purchased from Lonza.

\section{Purification and chemical functionalization of MWCNTs}

MWCNTs were first purified and functionalized by acidic treatment with $\mathrm{HNO}_{3}$. Typically, concentrated $\mathrm{HNO}_{3}(40 \mathrm{ml}, 14 \mathrm{M})$ were added to MWCNTs $(800 \mathrm{mg})$ in a round-bottom glass flask. The suspension was stirred overnight to guarantee homogenous dispersion of the nanotubes and then heated at $130{ }^{\circ} \mathrm{C}$ for $5 \mathrm{~h}$. After cooling at room temperature, it was filtered under vacuum by using cellulose filters with $0.2 \mu \mathrm{m}$ pore size and several washes in distilled water in order to eliminate any acidic residues. Once the $\mathrm{pH}$ in the washes was stabilized at 5.5, MWCNTs were freeze-dried for $24 \mathrm{~h}$ and stored until used. To simplify, the so obtained MWCNTs will be named as long MWCNTs (LN). The short MWCNTs (SN) were obtained by simple exposure of LN to a stronger acidic treatment. Particularly, $200 \mathrm{mg}$ of $\mathrm{LN}$ were sonicated for $4 \mathrm{~h}$ 
(DT102H, Bandelin Sondez Digitex) in a concentrated solution containing $\mathrm{H}_{2} \mathrm{SO}_{4}$ and $\mathrm{HNO}_{3}(12 \mathrm{ml}, 3: 1)$. The temperature in the bath was maintained below $40{ }^{\circ} \mathrm{C}$ along the process. After treatment, SN were allowed to cool down at room temperature, then repeatedly washed in distilled water and finally freeze-dried as described above.

\section{Preparation of cross-linked CNT-based scaffolds}

Chitosan/MWCNT cross-linked scaffolds were prepared by using the ISISA process as previously described. ${ }^{15,35}$ Briefly, chitosan solutions (1 wt \%) were made by dissolving chitosan (CHI, $0.1 \mathrm{~g})$ into an aqueous solution of acetic acid (10 g, $0.15 \mathrm{M}$, $\mathrm{pH}$ 4.5). Either LN or SN MWCNTs (300 mg) were then dispersed in the chitosan solution ( $5 \mathrm{~g}, 1 \mathrm{wt} \%)$ by stirring at room temperature for $24 \mathrm{~h}$ and finally sonicated for $4 \mathrm{~min}$. The suspension was then collected into insulin syringes $(1 \mathrm{ml})$ and two different freezing ISISA methodologies were applied in order to modify the scaffold channel dimensions. Some of the samples were dipped at a constant rate of $5.9 \mathrm{~mm} \mathrm{~min}^{-1}$ into a cold bath maintained at a constant temperature of $-196{ }^{\circ} \mathrm{C}$ (liquid nitrogen). In the other case, the suspensions were dipped at a constant rate of $0.9 \mathrm{~mm} \mathrm{~min}^{-1}$ into an ethanol bath at $-65{ }^{\circ} \mathrm{C}$ (dry ice). After this unidirectional freezing procedure, samples were freeze-dried using a thermoSavant Micromodulyo freeze-drier. The resulting monoliths were additionally exposed to glutaraldehyde vapors (GA, $50 \mathrm{wt} \%$ in distilled water) at room temperature for $24 \mathrm{~h}$ in order to obtain structure reinforcement by chitosan crosslinking. Finally, the so obtained scaffolds (LNCHI and SNCHI, containing either long or short MWCNTs, respectively) were aerated for $24 \mathrm{~h}$. A similar methodology was used for the fabrication of CNT-based scaffolds made of either chondroitin sulphate $(\mathrm{CHO})$ or gelatin (GEL). Both polymers were dissolved in distilled water (1 wt \%) prior to MWCNT addition. The resulting scaffolds were crosslinked by exposure to 
hexamethylene diisocyanate (HMDI) vapors at $37^{\circ} \mathrm{C}$ for 7 days. The so obtained scaffolds (LNCHO and SNCHO for chondroitin sulphate; LNGEL and SNGEL for gelatin) were also aerated for further $24 \mathrm{~h}$ before use. In all cases, singular scaffolds were obtained from freeze-dried monoliths by a similar procedure of cryo-fracture. Differences found between scaffolds are, therefore, attributed to the intrinsic scaffold composition and not to manipulation of the monolith.

Prior to the fabrication of CNT-based scaffolds, GEL was initially dissolved in distilled water at $50{ }^{\circ} \mathrm{C}$ for $3 \mathrm{~h}$ under stirring. After cooling at $4{ }^{\circ} \mathrm{C}$, the resulting hydrogel was dialyzed in distilled water and further dissolved at $50{ }^{\circ} \mathrm{C}$. The final solution was then freeze-dried and stored at $4{ }^{\circ} \mathrm{C}$ until used. As an additional precaution, nanotube dispersion and syringe preparation for GEL-containing scaffolds were performed at $37^{\circ} \mathrm{C}$ to avoid undesired gelation.

\section{Preparation of polymer-coated glass coverslips}

Solutions of $\mathrm{CHI}(2 \% \mathrm{w} / \mathrm{v}$ in acetic acid), $\mathrm{CHO}(6 \% \mathrm{w} / \mathrm{v}$ in distilled water $)$ and GEL ( $2 \% \mathrm{w} / \mathrm{v}$ in distilled water) were prepared and used to homogeneously coat circular glass coverslips by spin-coating at 500 (for $\mathrm{CHI}$ ) or $750 \mathrm{rpm}$ (for $\mathrm{CHO}$ and GEL). Further crosslinking of the coated coverslips was achieved by exposure to either GA or HMDI vapors for 30 min or 7 days, respectively.

\section{Scaffold characterization}

Details of scaffold architecture, cross-section morphology and pore size were examined by using a DSM-950 scanning electron microscope (SEM, Zeiss). Scaffold porosity was measured from SEM images by using the UTHSCSA ImageTool software, version 3.00. Briefly, pores were delimited in each scaffold image and their area 
converted to $\mu \mathrm{m}^{2}$ by calibration with the scale bars. Porosity was then expressed as pore area per $\mu \mathrm{m}^{2}\left(A_{P}\right)$ and pore width $\left(W_{P}\right)$. Additional SEM micrographs were acquired in a Hitachi S-4700 scanning electron microscope equipped with the MeX software package (version 5.0.1, Alicona) that allowed for 3D data acquisition and object reconstruction using stereo-photogrammetry. Specifically, the software identified common points at different focus depths on a block of three overlapped 2D images that were taken at different tilt angles $\left(5,0\right.$ and $\left.-5^{\circ}\right)$. Finally, the software allocated every point from the original 2D images into a 3D mapping that allowed object reconstruction. The root mean square (RMS) roughness $(R q)$ was obtained from the reconstructed 3D model of the different specimens for a path lenght of $15 \mu \mathrm{m}$.

The mechanical properties of the different scaffolds were measured at room temperature by using a Perkin-Elmer DMA7 equipment, as previously described. ${ }^{60}$ Briefly, the bending strength, $\sigma_{f}$, was determined by a three-point bending test and the Young's modulus calculated from the slopes of the load-deflection curves.

Scaffold conductivity was measured by using a four-point method. ${ }^{61}$ Particularly, a constant current $(1 \mathrm{~mA})$ was applied between contact points made of silver electrodes by using a digital multimeter Fluke 8840 . Two of the contact points were placed at the edges of the scaffold cylinder in the same longitudinal plane $(1 \mathrm{~cm}$ in length) with a pair of micromanipulators. The voltage drop in the scaffold surface was then measured by using another two silver electrodes located at the scaffold surface by slightly pressuring the scaffold with another pair of micromanipulators. The accuracy of the voltage measurement was approximately $1 \mu \mathrm{V}$. Conductivity was then calculated by using the following equation: $\sigma=\left[L /\left(\pi r^{2} \cdot R\right)\right]$, where $L$ is the distance between the electrodes on the upper part of the scaffold, $R$ is the measurement recorded by the multimeter and $r$ the diameter of the scaffold cylinder. 


\section{Cell culture}

Prior to cell culture, scaffolds ( $c a .4 .5 \mathrm{~mm}$ in diameter, $c a .3 \mathrm{~mm}$ in thickness) were sterilized under UV radiation for 20 min per side and preconditioned in culture medium for $24 \mathrm{~h}$ to eliminate any toxic residues from the synthesis. Three different cell types were tested: murine L929 fibroblasts, human osteoblast-like Saos-2 cells and porcine endothelial cells derived from peripheral blood progenitors $\left(\mathrm{EC}_{\mathrm{PC}}\right)$, obtained as previously described. ${ }^{62}$ A total of $10^{5}$ cells was seeded on the top part of the scaffolds in a small fraction of media (typically $30 \mu \mathrm{l}$ ) and allowed to attach for $20 \mathrm{~min}$. Immediately after, scaffolds were completely covered with complete media as follows: DMEM supplemented with fetal bovine serum $(10 \%)$, streptomycin $\left(100 \mathrm{UI} \mathrm{ml}^{-1}\right)$, penicillin (100 $\left.\mathrm{UI} \mathrm{ml}^{-1}\right)$, and L-glutamine $(1 \mathrm{mM})$ for fibroblasts and osteoblasts, and EGM-2 media for $\mathrm{EC}_{\mathrm{PC}}$ cells. Cultures were maintained in static conditions at $37{ }^{\circ} \mathrm{C}$ in a sterile incubator under a $\mathrm{CO}_{2}(5 \%)$ atmosphere for different times. Tissue culture polystyrene (TCP) was used as a control surface. Culture media was replaced every other day. Cell cultures were visualized by using an Axiovert CFL-40 optical microscope with an Axiocam ICC-1 digital camera coupled (Zeiss) when possible.

For cell size comparison, and assuming cells as entities with an ellipsoidal shape for simplification, cell dimensions were expressed as $l / w$ ratios, where $l$ is the cell length (i.e., the longest cell dimension) and $w$ the cell width (i.e., the shortest dimension). In this sense, the higher the value of the $l / w$ ratio is, the more elongated the cell morphology is; whereas a $l / w$ ratio close to the unitary value correlates with a more square cell shape. According to this, cell size was measured and averaged from at least 25 cells from each cell type either right after trypsin treatment for cell detachment (cells in suspension before seeding) or after culture on TCP for $48 \mathrm{~h}$ under standard culture conditions (adhered in culture). 


\section{Viability and apoptosis studies}

To test cell viability, cells cultured on the different substrates were analyzed by using a Live/Dead ${ }^{\circledR}$ Viability kit (Invitrogen) according to manufacturer’s instructions. This kit is based on the use of two probes: calcein and ethidium homodimer-1 (EthD-1). Calcein is a non-fluorescent cell-permeable dye that gets converted into a strongly green-light-emitting compound after contact with intracellular esterases and then retained inside live cells. On the contrary, EthD-1 is a DNA-intercalating agent that penetrates cell membranes in dead cells and emits orange/red fluorescence when inserted into the DNA double helix. After staining, samples were visualized by using a Leica SP5 confocal laser scanning microscope. The fluorescence of both probes was excited by an Argon laser tuning to $488 \mathrm{~nm}$. After excitation, emitted fluorescence was separated by using a triple dicroic filter 488/561/633 and measured at 505-570 nm for green fluorescence (calcein) and 630-750 nm for red fluorescence (EthD-1). Physical reflexion from the scaffolds after excitation at $488 \mathrm{~nm}$ was also recorded and used to visualize the scaffold structure and the relative cellular location. To quantify cell viability, at least 6 square fields were randomly distributed in 20x confocal images and the number of live (green), dead (red) and apoptotic (green and red) cells counted per square and averaged.

Apoptotic cells in the cultures were specifically detected by using an annexin VFITC apoptosis detection kit (Sigma). Briefly, Saos-2 osteoblasts and $\mathrm{EC}_{\mathrm{PC}}$ cells were cultured at a density of $5 \cdot 10^{4}$ cells per scaffold. Twenty-four hours after seeding, cell cultures were washed with PBS (twice) and incubated with annexin V-FITC conjugate ( $5 \mu \mathrm{l}$ in $500 \mu \mathrm{l}$ of PBS) for $10 \mathrm{~min}$ protected from light. Simultaneous staining with the probe EthD-1 allowed for the discrimination among early apoptotic (green 
fluorescence), late apoptotic (green and red) and dead cells (red). Stained cells were then visualized by using a Leica DMI 6000B fluorescence microscope. As a result of the externalization of phosphatidylserine, apoptotic cells were detected by their green fluorescence emission. Additionally, some cells were exposed to $\mathrm{H}_{2} \mathrm{O}_{2}$ (1 mM in PBS) for 90 min prior to annexin $\mathrm{V}$ incubation to serve as positive control of apoptosis induction. Cell viability in these cultures was tested in parallel as previously described.

\section{Cell adhesion and morphology studies by scanning electron microscopy (SEM)}

Cells cultured on the scaffolds for $48 \mathrm{~h}$ were rinsed in PBS twice and fixed with glutaraldehyde $2.5 \%$ in PBS for 30 min. After washing in distilled water, dehydration was performed by slow water replacement using series of ethanol solutions $(30 \%, 50$ $\%, 70 \%$, and $90 \%$ ) for 15 min twice and a final dehydration in absolute ethanol for 30 min. Samples were then allowed to dry at room temperature for $24 \mathrm{~h}$, and then mounted in stubs and coated in vacuum with gold. Cell cultures on scaffolds were examined with a DSM-950 scanning electron microscope (SEM, Zeiss).

\section{Time-lapse confocal laser scanning microscopy (CLSM) recording}

Cell migration on the different scaffolds was investigated by using time-lapse CLSM recording. Briefly, Saos- 2 cells were seeded at a density of $2.5 \cdot 10^{4}$ cells per scaffold and permitted to adhere on the scaffold surface for $20 \mathrm{~min}$. Due to the opacity of CNT-based scaffolds, cells were labeled to allow their visualization with alexa fluor ${ }^{\circledR}$ 594-conjugated wheat germ agglutinin (WGA, $5 \mu \mathrm{g} \mathrm{ml}^{-1}$ in PBS, Invitrogen), a fluorescent lectin that selectively binds to $\mathrm{N}$-acetylglucosamine and $\mathrm{N}$-acetylneuramic acid residues present in cell glycoproteins. After 5 minutes of incubation at room temperature, cell movements were recorded for at least 3 hours by using a Leica SP5 
confocal laser scanning microscope with an acclimatized chamber $\left(37^{\circ} \mathrm{C}, 5 \% \mathrm{CO}_{2}\right)$. Simultaneous laser reflection on the scaffold surface permitted a perfect visualization of the scaffold architecture. Cells on TCP were visualized without WGA staining as the transparency of the substrate allowed for their direct observation.

\section{Statistics}

Values were expressed as mean \pm standard deviation. Statistical analysis was performed using the Statistical Package for the Social Sciences software (SPSS), version 17.0. Comparisons among three or more groups were done by analysis of variance (ANOVA), followed by either Scheffé or Games-Howell post hoc tests depending on variance homogeneity among groups. For comparisons between two groups, $\mathrm{t}$ Student test was performed. In all statistical evaluations, $\mathrm{p}<0.05$ was considered statistically significant. 


\section{Additional Figures}

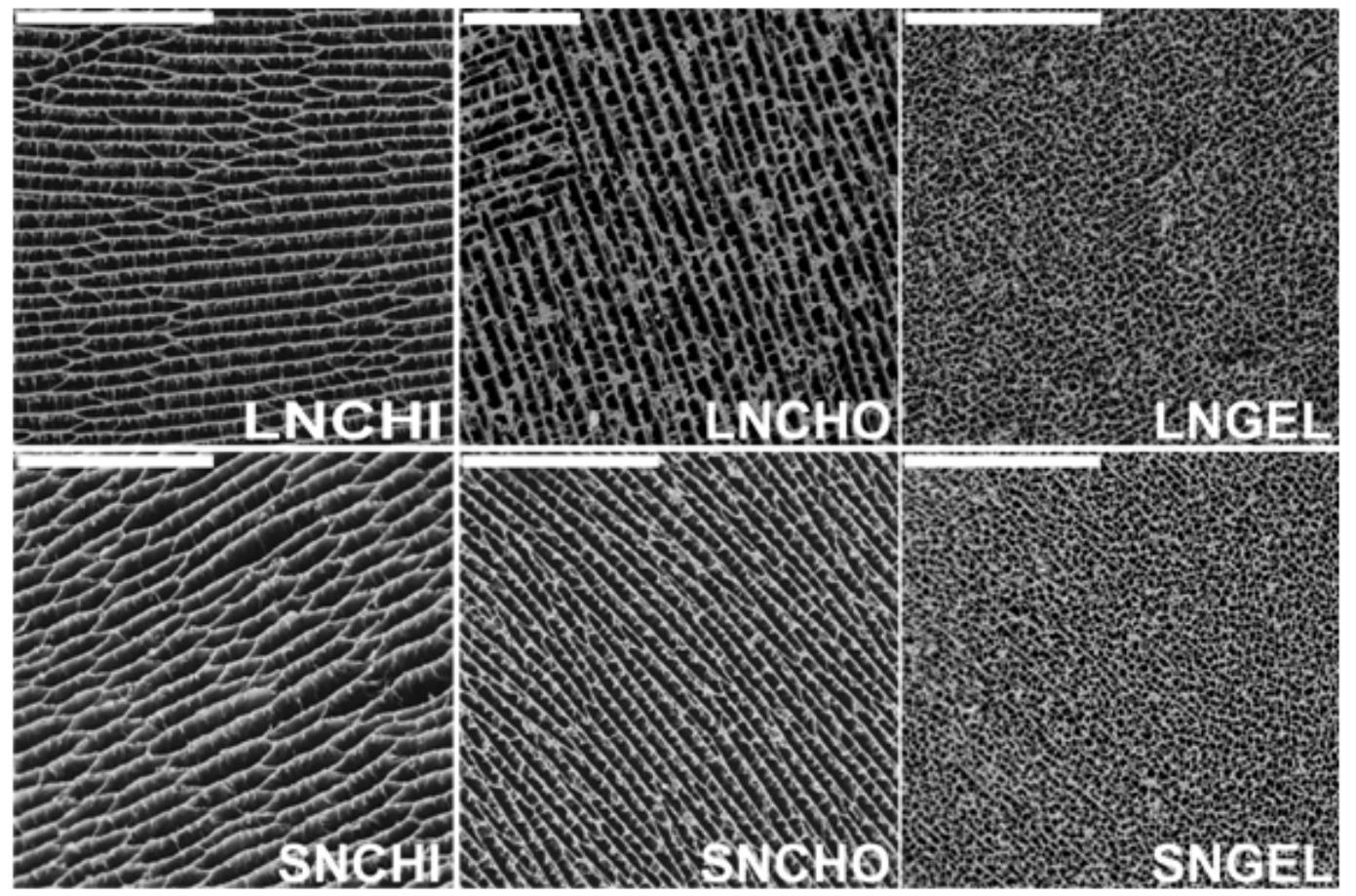

Figure 1-SI. Panoramic SEM micrographs of CHI-, CHO- and GEL-based scaffolds containing either long (LN) or short (SN) MWCNTs to appreciate the particular and homogeneous structure in each case. Scale bars represent $100 \mu \mathrm{m}$ (LNCHO) or $200 \mu \mathrm{m}$ (all the rest).

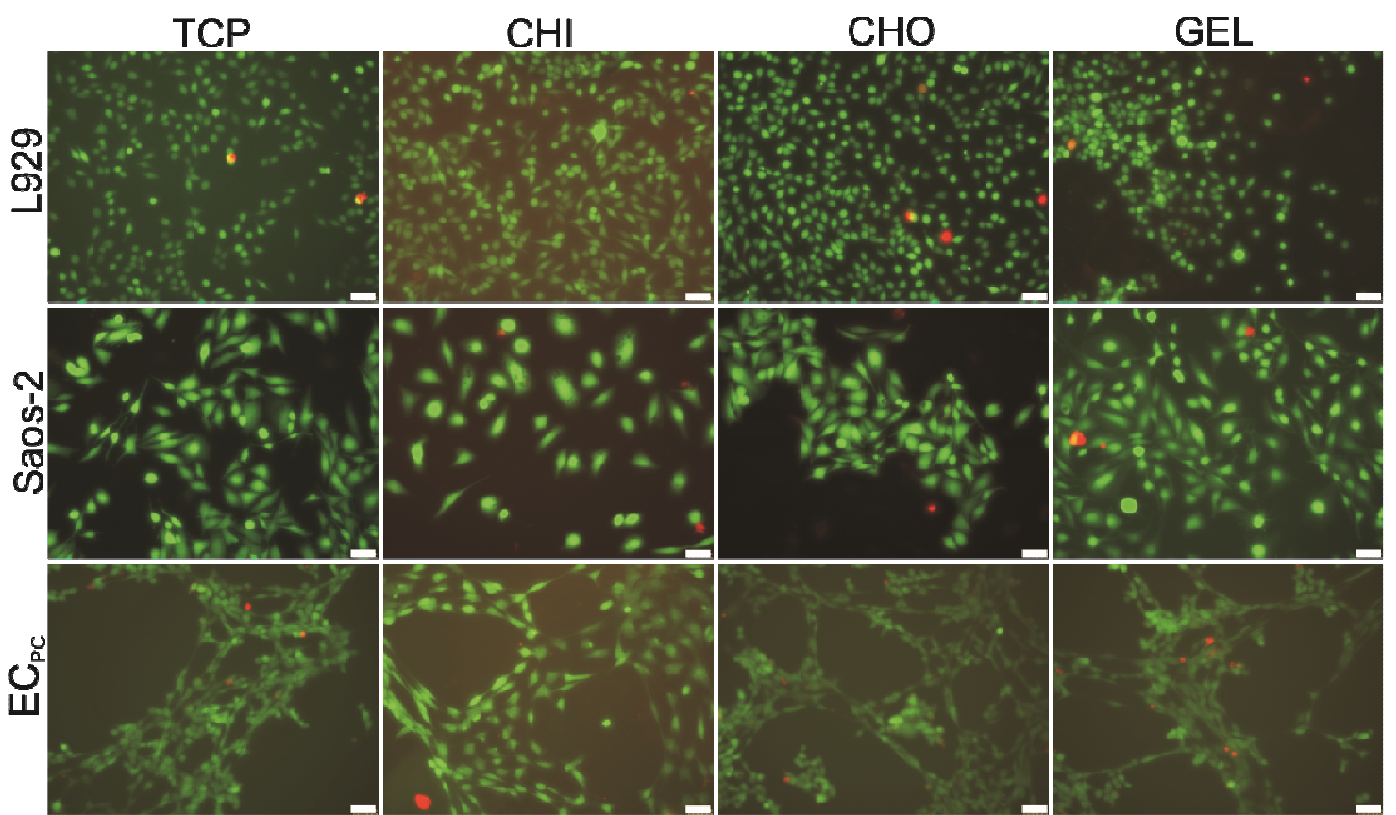

Figure 2-SI. Cell viability of L929 fibroblasts, Saos-2 osteoblasts and $\mathrm{EC}_{\mathrm{PC}}$ cells on CHI-, CHO- and GEL-coated glass coverslips. Dead cells appear stained in red, while live cells stain in bright green. Representative CLSM images of cultures at $48 \mathrm{~h}$ are shown. Scale bars represent $50 \mu \mathrm{m}$ in all images. 


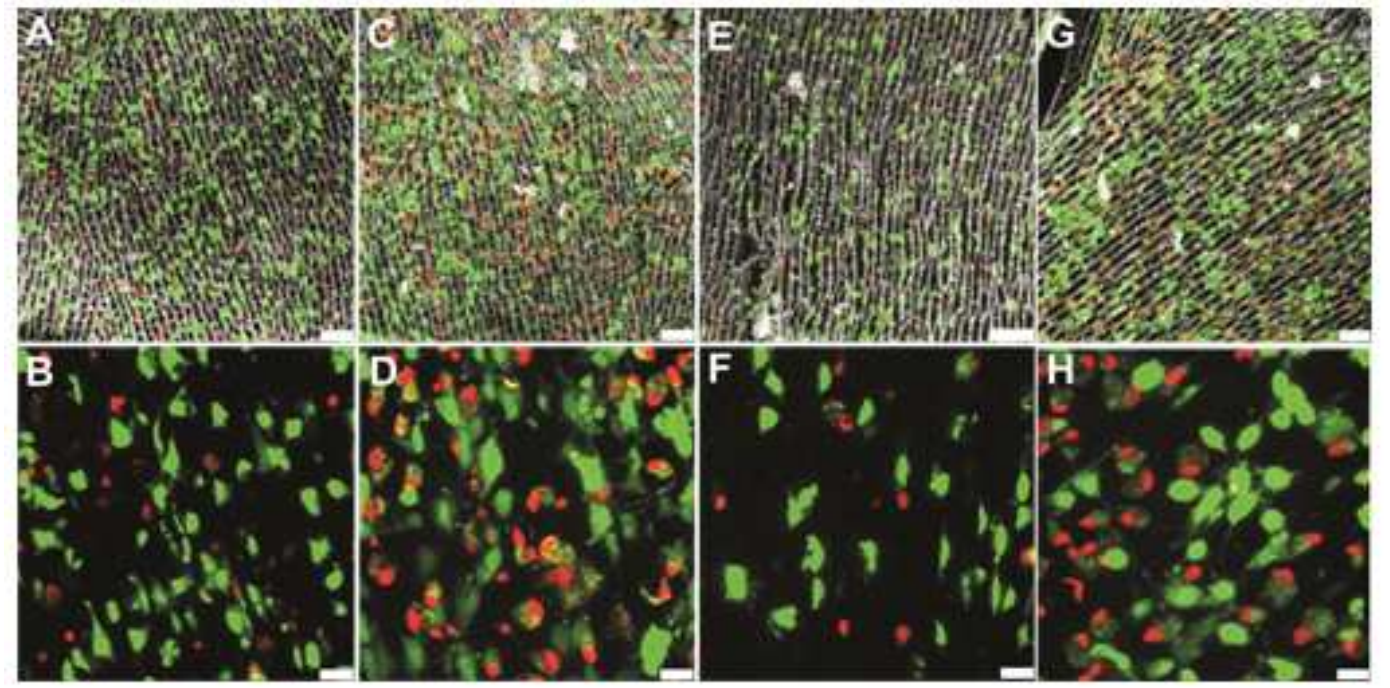

Figure 3-SI. Cell viability on LNCHI (A-D) and SNCHI (E-H) scaffolds. Human Saos2 osteoblasts $(\mathrm{A}, \mathrm{B}, \mathrm{E}, \mathrm{F})$ and porcine $\mathrm{EC}_{\mathrm{PC}}$ cells $(\mathrm{C}, \mathrm{D}, \mathrm{G}, \mathrm{H})$ were cultured on the different scaffolds for $48 \mathrm{~h}$. Dead cells appear stained in red, while live cells stain in bright green. Representative CLSM images are shown. Scale bars represent $75 \mu \mathrm{m}$ (top) or $25 \mu \mathrm{m}$ (bottom).
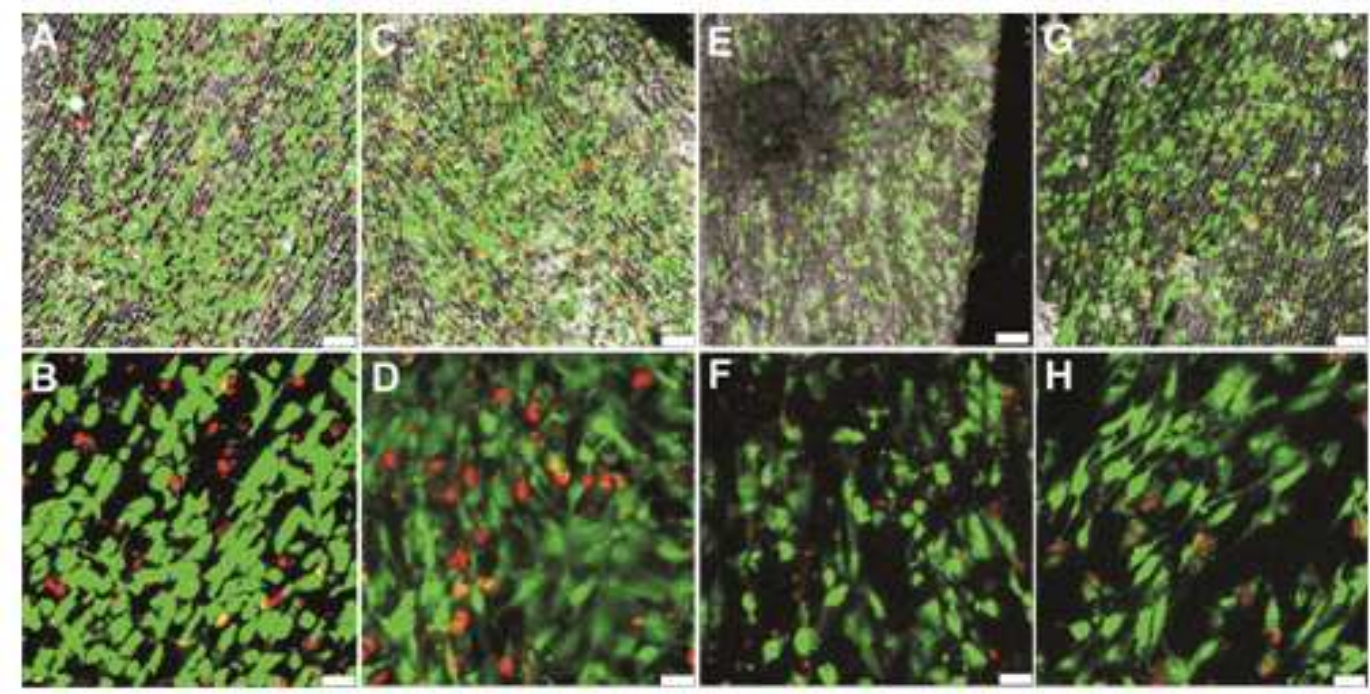

Figure 4-SI. Cell viability on LNCHO (A-D) and SNCHO (E-H) scaffolds. Human Saos-2 osteoblasts (A, B, E, F) and porcine EC $_{P C}$ cells $(C, D, G, H)$ were cultured on the different scaffolds for $48 \mathrm{~h}$. Dead cells appear stained in red, while live cells stain in bright green. Representative CLSM images are shown. Scale bars represent $75 \mu \mathrm{m}$ (top) or $25 \mu \mathrm{m}$ (bottom). 


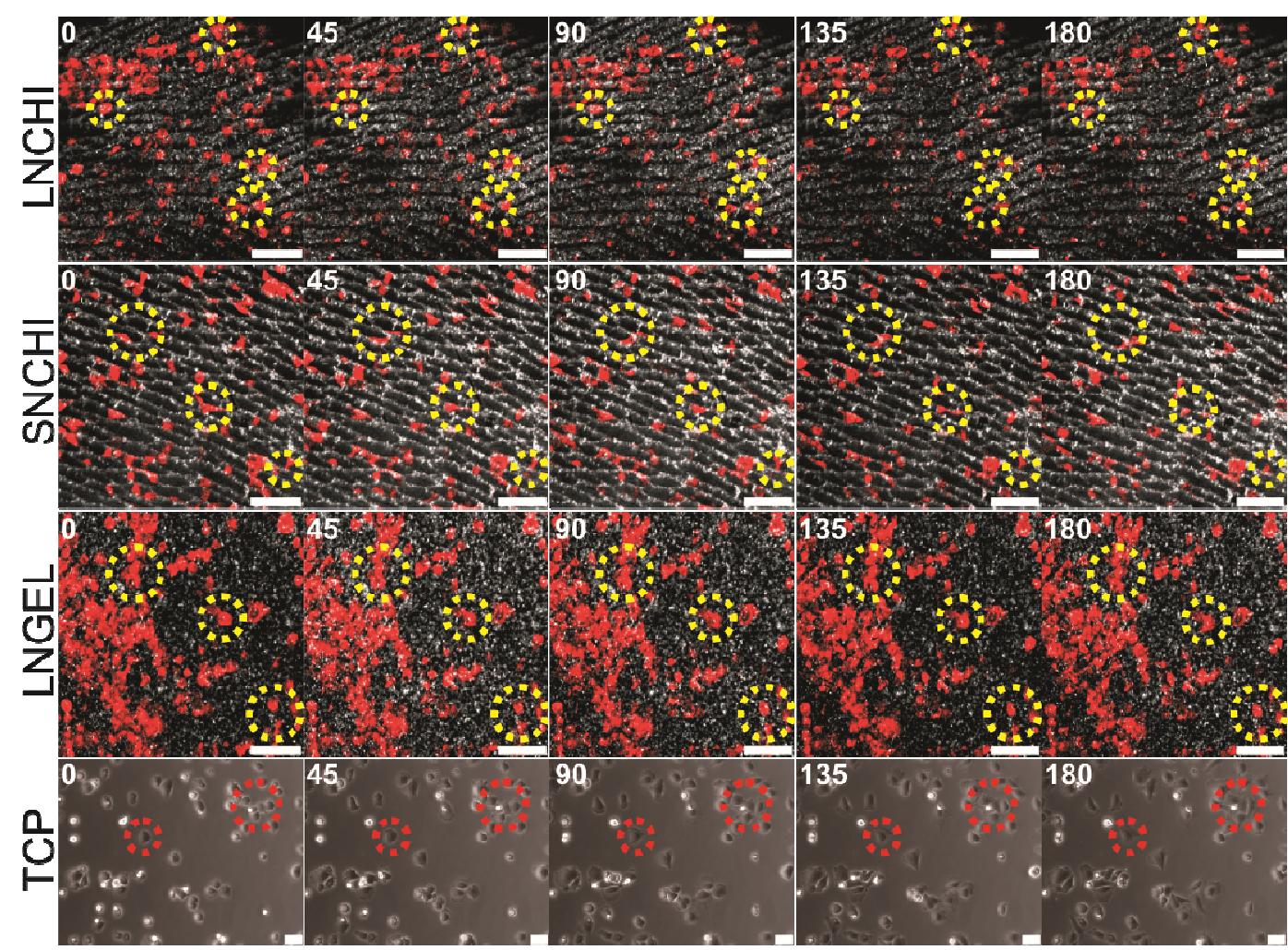

Figure 5-SI. Migration recordings by CLSM of Saos-2 cells cultured on LNCHI, SNCHI and LNGEL scaffolds. Cells were stained with WGA for visualization. Yellow circles are used to facilitate appreciation of cell migration. Numbers on the left top corner indicate time $(\mathrm{min})$. Scale bar represents $75 \mu \mathrm{m}$. Saos- 2 cells cultured on TCP are also included for reference. Scale bar on TCP represents $50 \mu \mathrm{m}$.

Movie 1-SI. Time-lapse CLSM recording of Saos-2 cell migration on LNCHI scaffolds.

Movie 2-SI. Time-lapse CLSM recording of Saos-2 cell migration on SNCHI scaffolds.

Movie 3-SI. Time-lapse CLSM recording of Saos-2 cell migration on LNGEL scaffolds. 